OCEAN DRILLING PROGRAM

\author{
LEG 168 SCIENTIFIC PROSPECTUS
}

\title{
HYDROTHERMAL CIRCULATION IN THE OCEANIC CRUST: \\ EASTERN FLANK OF THE JUAN DE FUCA RIDGE
}

\author{
Dr. Earl Davis \\ Co-Chief Scientist, Leg 168 \\ Pacific Geoscience Centre \\ Geological Survey of Canada \\ P.O. Box 6000 \\ Sidney, B.C. V8L 4B2 \\ Canada
}

\author{
Dr. Andrew Fisher \\ Co-Chief Scientist, Leg 168 \\ Earth Sciences Department \\ University of California, Santa Cruz \\ Earth and Marine Sciences Building \\ Santa Cruz, CA 95064 \\ U.S.A.
}

\section{Paul J. Fox \\ Director \\ Science Operations \\ ODP/TAMU}

Dr. John Firth

Staff Scientist, Leg 168

Ocean Drilling Program

Texas A\&M University Research Park

1000 Discovery Drive

College Station, TX 77845-9547

$$
\text { U.S.A. }
$$

Timothy J.G. Francis

Deputy Director

Science Operations

ODP/TAMU
Jack Baldauf
Manager Science Operations
ODP/TAMU


Material in this publication may be copied without restraint for library, abstract service, educational, or personal research purposes; however, republication of any portion requires the written consent of the Director, Ocean Drilling Program, Texas A\&M University Research Park, 1000 Discovery Drive, College Station, Texas 77845-9547, U.S.A., as well as appropriate acknowledgment of this source.

Scientific Prospectus No. 68

First Printing 1996

Distribution

Copies of this publication may be obtained from the Director, Ocean Drilling Program, Texas A\&M University Research Park, 1000 Discovery Drive, College Station, Texas 77845-9547, U.S.A. Orders for copies may require payment for postage and handling.

\section{$\underline{D} \underline{I} \underline{\mathrm{S}} \underline{\mathrm{C}} \underline{\mathrm{L}} \underline{\mathrm{A}} \underline{\mathrm{I}} \underline{\mathrm{M}} \underline{\mathrm{E}} \underline{\mathrm{R}}$}

This publication was prepared by the Ocean Drilling Program, Texas A\&M University, as an account of work performed under the international Ocean Drilling Program, which is managed by Joint Oceanographic Institutions, Inc., under contract with the National Science Foundation. Funding for the program is provided by the following agencies:

Canada/Australia Consortium for the Ocean Drilling Program

Deutsche Forschungsgemeinschaft (Federal Republic of Germany)

Institut Français de Recherche pour l'Exploitation de la Mer (France)

Ocean Research Institute of the University of Tokyo (Japan)

National Science Foundation (United States)

Natural Environment Research Council (United Kingdom)

European Science Foundation Consortium for the Ocean Drilling Program (Belgium,

Denmark, Finland, Iceland, Italy, The Netherlands, Norway, Spain, Sweden,

Switzerland, and Turkey)

Any opinions, findings, and conclusions or recommendations expressed in this publication are those of the author(s) and do not necessarily reflect the views of the National Science Foundation, the participating agencies, Joint Oceanographic Institutions, Inc., Texas A\&M University, or Texas A\&M Research Foundation.

This Scientific Prospectus is based on pre-cruise JOIDES panel discussions. The operational plans within reflect JOIDES Planning Committee and thematic panel priorities. During the course of the cruise, actual site operations may indicate to the Co-Chief Scientists and the Operations Superintendent that it would be scientifically or operationally advantageous to amend the plan detailed in this prospectus. It should be understood that any proposed changes to the plan presented here are contingent upon approval of the Director of Sciences Operations of the Ocean Drilling Program in consultation with the Planning Committee and the Pollution Prevention and Safety Panel. 


\begin{abstract}
Simple examples of several common hydrothermal flow regimes have been found on the eastern flank of the Juan de Fuca Ridge. Ocean Drilling Program Leg 168 will focus on two of these, at sites where (1) there is a sharp transition from sediment-free to sediment-covered igneous crust, where heat flow, crustal temperatures, basement fluid compositions, and upper crustal seismic velocities all show large systematic changes associated with the transition from open to closed hydrothermal circulation, and where (2) buoyancy-driven fluid flow within the igneous crust and through the seafloor is strongly influenced by basement relief and sediment-thickness variations. If time permits, a third site may be studied where particularly flat basement and regionally continuous sediment cover should prevent advective heat loss and allow the total heat flow from this young lithosphere to be determined confidently. All of these examples represent situations that occur commonly in all ocean basins, but because of the unusual simplicity of the occurrences in this area, they provide ideal targets for drilling.
\end{abstract}

Sampling, downhole measurements, and postdrilling observations will be directed mainly toward elucidating the physics and fluid chemistry of ridge-flank hydrothermal circulation, and the consequent alteration of the upper igneous crust and sediments that host the flow. Two arrays of relatively shallow holes will provide direct information about lateral gradients in basement fluid composition, formation pressures, and temperatures and strong constraints on formation-scale heat-transport properties of the upper igneous crust and the vigor of circulation.

\title{
INTRODUCTION
}

While the most spectacular manifestation of oceanic crustal fluid circulation is found along mid-ocean ridge axes in the form of high-temperature $\left(350^{\circ}-400^{\circ} \mathrm{C}\right)$ springs that deposit metal-sulfide minerals, a far greater flux of both heat and seawater occurs via hydrothermal circulation in the igneous crust of mid-ocean ridge flanks. Modelling and observations of heat flow indicate that advective heat loss globally through ridge flanks is more than triple that at ridge axes, and because this heat is lost at lower temperatures the volumetric flux of seawater through the flanks is proportionately even greater, more than 10 times that at the axes. Significant hydrothermal heat loss and fluid exchange between the crust and ocean typically continue to an age of several tens of millions of years, and thus effect more than one-third of the ocean floor (Anderson et al., 1977; Sclater et al., 1976). This process plays an important role in the alteration of oceanic crust, which includes changes in its chemistry, mineralogy, 
and physical properties such as seismic velocity and attenuation (Alt et al., 1986; Jacobson, 1992; Purdy, 1987). However, because of the wide range of conditions on ridge flanks, and the limited amount of work done there to date, we know little about these processes in detail. Major questions remain: what mechanisms drive fluid flow through the crust and seafloor, what is the magnitude of elemental chemical exchange between the crust and water column, and what factors are the most important influence on water/rock interactions and thus control fluid chemistry and the chemical and physical alteration of the crust?

Over the past two decades, several sites of hydrothermal circulation on mid-ocean ridge flanks have been investigated. These include the Galapagos mounds, the southern flank of the Costa Rica Rift, the equatorial East Pacific Rise flanks, the western flank of the East Pacific Rise near $20^{\circ} \mathrm{S}$, the western flank of the Mid-Atlantic Ridge, and the flanks of the Mariana Trough spreading axis. These sites represent a wide range in sediment thickness and continuity, sediment type, crustal age, and basement topography. Although these localities display a correspondingly wide range of hydrothermal conditions and processes, our understanding of the processes remains only semi-quantitative.

As a result of several surface-ship and submersible programs completed during the past seven years, the eastern flank of the Juan de Fuca Ridge has become one of the most thoroughly studied ridge flanks. Representative examples of many of the hydrothermal environments found elsewhere have been discovered and examined in detail, and the crustal seismic structure has been imaged particularly well. By providing critical hydrologic, geophysical, and geochemical samples and observations of three subseafloor fluid-flow "type-example" systems that occur in remarkably simple form on this ridge flank; Leg 168 wll reveal more information on the nature of crustal evolution. The leg will take advantage of recent ODP technological advances including improvements to several tools that will greatly enhance the chance of success and the efficiency of operations of the program.

\section{STUDY AREA}

The Juan de Fuca Ridge is a seafloor spreading center that lies a few hundred kilometers off the coast of North America. It supplies crust and lithosphere to the Pacific and Juan de Fuca plates at rates of about 56 mm/yr (Fig. 1; for reviews, see Johnson and Holmes, 1989; Davis and Currie, 1993). The topographic relief of the ridge (Fig. 2) produces a barrier to terrigenous turbidite sediment supplied from Pleistocene glacial sources along the continental margin, primarily at Queen Charlotte Sound, Juan de Fuca Strait, and the Grays Harbor and Columbia River estuaries. This situation has resulted in the accumulation of an onlapping 
layer of sediment that buries the eastern flank of the Juan de Fuca Ridge. This sedimented region known as Cascadia Basin extends from the base of the continental margin, where accretion of the sediment entering the Cascadia subduction zone begins, to within a few tens of kilometers of the ridge crest, where sediment laps onto crust that is at some locations younger than $1 \mathrm{Ma}$ (Fig. 3). Along the deformation front of the Cascadia accretionary prism the sediment layer is over $3 \mathrm{~km}$ thick in places; in general, the fill in the northern part of the basin is sufficient to completely bury the relief of the igneous crust of the Juan de Fuca plate, with the exception of only a few isolated volcanic cones and seamounts.

Beneath the nearly continuous, flat-lying sediment cover, local basement relief is dominated by linear ridges and troughs that were produced by normal faulting and variations in volcanic supply at the time the crust was created. The amplitude of this relief varies across the basin. At a point roughly $100 \mathrm{~km}$ east of the ridge axis there is a fairly sharp boundary between areas of relatively smooth and rough basement relief. To the east, basement relief ranges typically from 300 to $700 \mathrm{~m}$, with ridges separated typically by 3 to $7 \mathrm{~km}$. Closer to the ridge crest, the crust is much smoother, with local relief typically only $100-200 \mathrm{~m}$.

The sediments that blanket the eastern flank of the ridge provide a conveniently soft layer in which heat-flow measurements can be made and a relatively low-permeability, porous "filter" from which pore fluids can be extracted. The degree of sediment burial makes fluid venting relatively rare, but highly focused and hence easily studied. The combination of watercolumn studies, detailed seafloor heat-flow and pore-fluid geochemical measurements sited along closely-spaced seismic reflection profiles, and direct submersible observations has provided strong constraints on the directions and rates of fluid flow through the seafloor and on the thermal structure, patterns of fluid flow, and pore-fluid composition within the upper igneous crust (e.g., Davis et al., 1992; Mottl and Wheat, 1994; Wheat and Mottl, 1994; Thomson et al., 1995). These studies form the framework for the drilling program planned for Leg 168.

Of particular interest are the remarkably simple examples of three general type-examples of crustal fluid-flow regimes found on this ridge flank that have become the focus of several detailed studies. These three type-examples comprise (1) a transition zone between sedimentfree (permitting open hydrothermal circulation) and sediment-covered (hydrologically sealed) crust, (2) an area where rugged basement topography and large variations in sediment thickness are inferred to exert a dominant influence on the pattern and rate of fluid flow within the upper igneous crust and through the seafloor into the water column, and (3) an area where a uniform and regionally continuous cover of sediments over unusually flat-lying basement 
should prevent advective heat loss and allow the total lithospheric heat flow to be determined with confidence. Each of these simple and well-characterized examples of common and important subseafloor hydrologic regimes is particularly well suited to the quantitative studies proposed here. Although the crust in which they occur is unusually young, similar situations can be found on virtually all ridge flanks, and the lessons learned will be extremely valuable for understanding the fundamental nature and consequences of crustal fluid flow as it occurs throughout the world's oceans.

\section{SCIENTIFIC OBJECTIVES AND METHODOLOGY}

\section{Summary of Objectives}

The primary objectives of ODP Leg 168 are focused on exploring the causes and consequences of ridge-flank hydrothermal circulation through drilling a suite of relatively shallow holes that will allow observations of lateral gradients of temperature, pressure, fluid composition, and rock alteration. Stated in general terms, the objectives are (1) to determine the thermo-physical characteristics of hydrothermal circulation in the upper oceanic crust in off-axis settings as influenced by crustal topography, sediment cover, and permeability; (2) to determine the sensitivity of crustal fluid composition to the age, temperature, and degree of sediment burial of the igneous crust; (3) to examine the nature and fundamental causes of physical consolidation and of mineralogical and chemical alteration of the igneous crust as functions of age and degree of sediment burial; and (4) to improve constraints on the fluxes of heat and elements between the permeable igneous crust and the overlying ocean. The program will address these questions in the true spirit of a field experiment, in which several hypotheses will be critically tested with observations that can be made by drilling in each of the type-example areas.

\section{Transition from Open to Sediment-sealed Hydrothermal Circulation}

About $20 \mathrm{~km}$ east of the axis of the Endeavour segment of the Juan de Fuca Ridge, the elevated relief of the ridge crest plunges beneath the western edge of Cascadia Basin (Fig. 4). A fundamental change in the nature of hydrothermal circulation occurs in this area. West of the edge of the abyssal plain turbidites, basement is covered by a relatively thin (less than $1 \mathrm{~m}$ to a few tens of meters), discontinuous veneer of hemipelagic sediment through which fluids can pass with little hydrologic impedance, whereas to the east, the igneous crust is blanketed continuously by turbidite sediments that create a hydrologic barrier. Heat flow and estimated upper crustal temperatures, seismic velocities in the upper crust, and estimates of basement pore-fluid compositions all show clear lateral gradients that are probably associated with the 
transition from open to sealed hydrothermal circulation (Fig. 5). Heat flow and estimated basement temperatures increase systematically to the east, away from the area of exposed basement (Davis et al., 1992). Estimated temperatures in the upper igneous crust increase from less than $10^{\circ} \mathrm{C}$ near where basement rocks outcrop to about $40^{\circ}-50^{\circ} \mathrm{C} 20 \mathrm{~km}$ to the east. Over the same distance the average heat flow increases from less than $15 \%$ to more than $80 \%$ of the value expected for the underlying lithosphere. Basement pore-fluid compositions estimated from sediment pore-fluid studies (Wheat and Mottl, 1994) change from close to that of seawater near the outcrop to strongly depleted in magnesium and enriched in calcium at a location $20 \mathrm{~km}$ to the east. Inferred chlorinities of the fluids in basement $20 \mathrm{~km}$ east of the point of burial are considerably higher than seawater. At least part of the increased chlorinity must be due to ongoing hydration reactions in the crust. This is consistent with the increase in basement temperature and with seismic data, which also reveal a systematic change. Interval velocities determined for the upper crustal seismic Layer $2 \mathrm{~A}$ increase from values that range from $3000-3500 \mathrm{~m} / \mathrm{s}$ to values exceeding $5000 \mathrm{~m} / \mathrm{s}$ over the same spatial interval of about $20 \mathrm{~km}$ (Rohr, 1994). While these velocities have been determined for a layer known to have strong vertical velocity gradients, they probably indicate a significant increase in velocities throughout Layer $2 \mathrm{~A}$. The increase is believed to indicate a decrease in porosity from alteration (e.g., Wilkens et al., 1991). A similar magnitude of change occurs on other ridge flanks (e.g., Houtz and Ewing, 1976), although at a much slower rate, probably because of the much more gradual hydrologic isolation of the upper igneous crust. The rapid burial of the crust on the eastern Juan de Fuca flank has accelerated the process and made it possible to relate unambiguously the change in seismic velocities to a measured change in the hydrothermal regime.

Drilling in this area of "Hydrothermal Transition" will address numerous fundamental questions about lateral fluid and heat transport and about the physical and chemical alteration of the crust that results from water-rock interaction. Specific questions include:

1. How does chemical and thermal transport take place over distances of $10-20 \mathrm{~km}$ in sediment-covered igneous crust? If there is a net horizontal transport of fluid, what is the rate?

2. What is the source and magnitude of the pressure gradient that drives the flow?

3. How do the changes in fluid chemistry and temperature with distance from sediment-free areas affect the nature of rock alteration? 
4. What is the dominant factor responsible for the increase in upper crustal velocity?

5. Is there an accompanying decrease in permeability?

6. At what rate does the alteration take place?

If it is found that crustal alteration is rapid and is primarily a function of temperature and fluid chemistry, then the results of studying this simple hydrothermal transition zone can be generalized to all ocean basins. That this is the case is strongly suggested by the coincidence of the heat-flow, geochemical, and seismic transitions shown in Figure 5, by the high and stable values of upper crustal seismic velocities observed to the east of the Hydrothermal Transition zone, and by the return to more normal (just above seawater) basement-fluid chlorinities observed in an area farther east.

\section{Topographically Enhanced Fluid Flow}

At a point roughly $100 \mathrm{~km}$ from the ridge axis, there is an abrupt change from the region of relatively smooth basement, typified by the "Lithospheric Heat Flow" drilling site discussed below, to a region where the basement surface is much more rugged. In this region, basement topography consists primarily of linear ridges and troughs produced by blockfaulting and by variations in volcanic supply at the time the seafloor was created. Local relief between ridges and troughs of 300 to $500 \mathrm{~m}$ is common, and major ridges are separated typically by 3-7 km (e.g., Fig. 6). All of this relief is now buried by the turbidites of Cascadia Basin. The tops of two ridges lie a few tens to a few hundreds of meters below the sediment surface. At three locations along these ridges, small volcanic edifices rise above the sediment surface to form small, isolated basement outcrops (Figs. 7, 8).

It has long been suggested that basement topography and local basement outcrops play a key role in seafloor hydrogeology by serving to enhance buoyancy-driven flow (e.g., Fisher et al., 1990; Fisher and Becker, 1995; Hartline and Lister, 1981; Lowell, 1980) and to focus flow from the igneous crust into the oceans (e.g., Lister, 1972; Davis and Becker, 1994). The simplicity of the local structure and the small size of the volcanic outcrops in this part of the east flank of the Juan de Fuca Ridge make the area an ideal target for seafloor studies. Results of a series of systematic surveys have confirmed several things about fluid flow in the crust and discharge through the seafloor in this environment:

1. Fluid circulation within the upper oceanic crust is sufficiently vigorous to maintain relatively uniform temperatures at the sediment/basement interface, despite variations of 
sediment thickness of more than a factor of 5 (Davis et al., 1992).

2. In the few locations where samples could be obtained, basement-fluid compositions also appear locally homogeneous (Mottl and Wheat, 1994).

3. Fluids leak through the sediment "seal" above buried basement ridges at geochemically detectable rates ( $<1$ to tens of $\mathrm{mm} / \mathrm{y}$ ) that are inversely proportional to the local sediment thickness (Davis et al., 1992).

4. Fluids flow through the basement outcrops at rates sufficient to generate detectable thermal, chemical, and light transmissivity anomalies in the water column (Thomson et al., 1995).

5. Discharge through the outcrop has been sufficiently long-lived to allow significant hydrothermal precipitates to accumulate. Cores from the outcrop have recovered green clay, semilithified black ferromanganese crusts and layers, and reddish iron oxides in indurated sediment (Mottl et al., 1993).

6. The thermal structures of all three basement outcrops are fundamentally the same, allowing us to conclude that upflow and discharge not only are stable and long-lived, but also are a general consequence of the permeability and temperature structure of what we referred to as "Permeable Penetrators" (Figs. 7, 8).

Although the nearly complete burial of the outcrops in this area makes them exaggerated examples, they are representative of a general class of circulation that is present wherever the crustal topographic relief of mid-ocean ridge flanks is partially filled in by sedimentation. An example of an "early" phase is the region of North Pond on the Mid-Atlantic Ridge flank studied by Langseth et al. (1992). A relic, fully buried example was probably intersected at Site 417 on the Mid-Atlantic Ridge flank (Donnelly et al., 1980). A highly focused and very active example was investigated during Leg 139 in the Middle Valley rift (Site 858, Dead Dog vent field; Davis and Becker, 1994).

Examples of topographically influenced circulation within the upper igneous crust occur on the Costa Rica Rift flank (holes in the vicinity of and including Hole 504B; e.g., Langseth et al., 1988; Mottl et al., 1989), and possibly on the northern flank of the Galapagos spreading center (Green et al., 1981). Again, the high degree of burial makes the Juan de Fuca Ridge flank an exaggerated example of topographically influenced fluid flow, but one that is ideally 
suited to the study planned for Leg 168.

Whereas the general characteristics of fluid flow within the crust and through the seafloor in this environment are reasonably well constrained, proper quantification of the hydrologic regime and elucidation of the consequences of fluid flow require drilling. With the array of holes planned, the following questions can be addressed:

1. To what degree are basement fluids thermally and chemically homogenized by circulation in this environment?

2. What implications can be drawn about the bulk hydrologic transport properties of the upper crust from constraints gained from observations of lateral temperature, pressure, and compositional gradients?

3. How is permeability distributed within upper basement?

4. To what degree has hydrothermal alteration of the crust proceeded at this 3.5-Ma site?

5. How have physical properties, namely velocity and permeability, changed with alteration?

6. What are the nature and magnitude of the forces that drive fluid flow through the sediment section above basement ridges and through "Permeable Penetrators," where basement is exposed at the seafloor?

7. What is the source of the fluids that vent through the seafloor at the outcrops? Do they simply come from the inferred homogeneous basement "reservoir" regionally sealed beneath the sediments or is there a component from a deeper source?

8. How are sediments chemically and physically affected by fluid seepage? Can a declining rate of seepage through the sediment section be tracked through the history of burial?

9. What is the nature of recharge? Is seawater supplied to the crust solely by regional diffuse flow through the sediments away from basement highs, or do some fluids enter the crust via locally focused pathways? 


\section{Lithospheric Heat Flow}

In a region spanning $\sim 60$ to $100 \mathrm{~km}$ from the ridge crest, igneous basement is relatively smooth and continuously sedimented (Fig. 9). A suite of parallel seismic lines running perpendicular to the ridge demonstrates that this character is continuous for at least $30 \mathrm{~km}$ along strike. Because the sediment layer covering basement is so uniform and regionally extensive, the site provides an ideal target for determining accurately the level of total heat loss from young oceanic lithosphere. Local heat-flow variability normally associated with sediment thickness variations should be small, and the closest basement outcrops through which undetected heat could be lost advectively are sufficiently far away that they should have an insignificant effect.

Accurate determination of the "normal" total rate of heat loss from oceanic lithosphere has been pursued for as long as marine heat-flow measurements have been collected. Obtaining high-quality lithospheric heat-flow "calibration" data has been extremely difficult, however, because of the perturbing effects of hydrothermal circulation that are usually very difficult to avoid (e.g., Sclater et al., 1976). Many studies critically depend on knowing the relationship between lithospheric heat flow and age. The heat flow vs. age relationship allows determination of estimates of deep-rock thermal properties (e.g., Lister, 1977). It allows accurate estimation of global heat loss using the known global distribution of seafloor age (e.g., Williams and Von Herzen, 1974). An accurate background "reference" heat flow vs. age relationship allows the thermal anomalies associated with mantle plumes, asthenospheric convection, and widespread reheating events to be determined (e.g., Von Herzen et al., 1982). And, of course, it allows estimation of local and regional hydrothermal fluid budgets (see Fig. 5).

In the past, heat-flow measurements were attempted in this otherwise ideal study area, but shallow sandy layers prohibited probe penetration. As an alternative, temperature and thermal conductivity data from a single borehole could provide an accurate estimate of the regional basement temperature. This, combined with the well-determined depth to basement defined by the seismic data and the knowledge that efficient lateral hydrothermal heat transport maintains an effectively isothermal sediment/basement surface will allow an excellent determination of the regional lithospheric flux to be made. In addition to addressing this objective, drilling at this 2.8-Ma site, which is located between the two principal sites (1.0 and 3.5 Ma), will also provide intermediate samples of basement rocks and water along the overall transect from relatively fresh to hydrothermally altered oceanic crust. 


\section{DRILLING, LOGGING, AND POST-DRILLING OPERATIONS STRATEGY}

Although virtually all individual holes planned for Leg 168 are separated by greater distances than normal for single-site specifications (i.e., as defined by the range for single-beacon acoustic navigation), the holes have been grouped into three operational "super sites" according to geographic area and primary objectives: (1) the Hydrothermal Transition site, (2) the Permeable Penetrators site, and (3) the Lithospheric Heat Flow site.

The specific drilling strategy to be adopted during the leg involves a mixture of conventional drilling, coring, and reentry operations arranged in a sequence of single holes at each site (Table 1). It represents a departure from traditional ODP operations, but provides an efficient means by which the primary objectives, including the safe establishment of four cased reentry holes sealed with CORK hydrologic observatory installations, can be met during the 56 days allotted to the leg. There is a considerable amount of excellent work that cannot be fitted into the time frame of the leg, given the estimated operations schedule. This work has been included in Table 2 as a suite of second priority holes. Any time gained (e.g., through more efficient casing and CORK operations at reentry holes) could allow additional drilling, coring, and downhole measurements at one or more of the second priority sites, although the likelihood of this possibility is unclear until the program is well underway.

Leg 168 will begin by coring two holes with the Advanced Hydraulic Piston Corer (APC) and Extended Core Barrel (XCB) at proposed Sites HT-1A and HT-2A. These holes will be cored only to the top of basement; coring will end with the first recovery of basalt (or with any other reliable indication that basement has been reached if there is no recovery).

Although it would be scientifically desirable to collect additional basalt cores within upper basement at these sites, such operations could jeopardize the hydrologic experiments planned for nearby proposed Sites HT-3A and HT-4A if the hydrologic seal overlying the most permeable upper volcanic basement is breached. Frequent measurements of in-situ temperature and frequent whole-round sampling for geochemistry and physical properties will accompany all APC/XCB coring, as described in the next section. Drilling will be completed at Sites HT-1A and HT-2A without tripping the drill string back to the rig floor; the ship will be dynamically positioned from site to site. Acoustic beacons will be dropped for all HT holes under Global Positioning System (GPS) navigational control prior to the deployment of the drill string at Site HT-1A. No underway geophysical data will be required at any of the sites.

Upon completion of operations at Site HT-2A, the ship will be dynamically positioned 
toward Site HT-4A and a jet-in test will be conducted in preparation for reentry and casing operations (preferably as far from Site HT-4A as possible). The drill string will then be returned to the surface, and a reentry cone and 16" conductor casing assembled. This assembly will be lowered to the seafloor at Site HT-4A along with a bottomhole assembly (BHA) for the Rotary Core Barrel (RCB). The casing will be jetted in and released, and RCB coring will continue to basement. Coring will be continued into basement only deep enough to find a suitable casing and cementing point, probably about $10 \mathrm{~m}$ below the sediment/basement interface. This will constitute the pilot hole. We will follow this nested approach to eliminate the high risk of hydrologic disturbance from a separate pilot hole. Following completion of the RCB operations, the hole will be enlarged to accept a casing string, which will then be assembled and run into the hole. After the casing is cemented into place, RCB coring will continue into upper basement for an additional $~ 30 \mathrm{~m}$ into the permeable and hydrologically active part of the upper igneous crust. Additional drilling may be required to reach this "hydrologic basement." The pipe will then be tripped back to the surface, and a packer BHA assembled for quantification of the bulk permeability of upper basement. A flowmeter log (Becker et al., 1994) will be run as part of packer operations, should initial testing with the packer alone indicate the presence of significant bulk permeability. The flowmeter log should give an indication of the distribution of permeability in uppermost basement (although more complete quantification of this distribution must await deeper basement drilling). It will also provide a check on the quality of the hydrologic seal around the cemented casing shoe. After packer operations have been completed, the pipe will be returned to the surface and a CORK assembled and deployed. The CORK body will be lowered into the reentry cone and casing, followed by the data logger and the sensor/sampling cable, which will span the cased section and extend into the open hole below. The cable will include 10 thermistors distributed along its length, with a concentration of thermistors at the bottom (for monitoring of open basement), and an osmotic fluid sampler located in the open section of the hole. The CORK instrumentation will provide a continuous record of formation pressure, temperature, and basement-fluid chemistry for a period of up to several years following deployment and permit observations to be made of the transient recovery from disturbances caused by drilling of equilibrium formation conditions and of any natural hydrologic variations.

Operations at Site HT-3A will be postponed until near the end of the leg. This will provide optimum flexibility if contingency plans need to be reviewed. Site HT-3A is considered the lowest priority of those to be instrumented with CORKs.

Following operations at Site HT-4A, the ship will transit to the Permeable Penetrator Site 
PP-1A and operations will continue with a single APC/XCB hole to the top of basement. Logging will be conducted after the completion of coring operations. Another APC/XCB hole will be drilled at Site PP-3A, and a jet-in test conducted for Site PP-4A. A complete reentry system, casing, and CORK will then be deployed at Site PP-4A, with RCB coring completed through the reentry cone, as at Site HT-4A. This hole may also be logged, depending on results of logging at Site PP-1A and on time constraints. A single-hole coring, casing, and CORK operating sequence will then be completed at Sites PP-5A and HT-3A, again following the sequence of operations at Site HT-4A, including pre-CORK packer tests. Total penetration into basement will also be $\sim 40 \mathrm{~m} \mathrm{(30} \mathrm{m} \mathrm{below} \mathrm{the} \mathrm{casing} \mathrm{shoe)} \mathrm{as} \mathrm{an} \mathrm{initial}$ target.

If, at the end of packer operations at Site PP-5A, it is anticipated that insufficient time is available for drilling, reentry system installation, packer work, and CORK deployment at Site HT-3A, the fourth CORK installment of Leg 168 will be abandoned. The time will be used for additional basement penetration and/or work at the second priority sites listed in Table 2.

Specifically, additional work could include (1) continued drilling deeper into basement and downhole measurements at Site PP-5A (prior to CORK installation), (2) a third hole ( Site $\mathrm{PP}-10 \mathrm{~A})$ drilled into the basement ridge, located along strike from Sites PP-3A and PP-5A, (3) a hole (Site PP-2A) into sediments between the buried ridge ( Site PP-3A) and trough (Site PP-1A) , (4) one or more holes drilled at Site PP-6A (RCB) and/or Site PP-7A-PP-9A (APC/XCB) at the basement outcrop, (5) APC/XCB coring at Site LH-2A, or (6) APC/XCB coring at Site HT-3A. The time required for each of these options is listed in Table 2 . The estimate given for the deepening of Site PP-5A is for $100 \mathrm{~m}$ (one bit) of advance. In the event the fourth CORK hole cannot be drilled, the decision about what additional work will be completed will be based on the results of the leg at that point, and will be made by the CoChief Scientists, in consultation with the Operations Superintendent, Staff Scientist, and the Leg 168 scientific party.

\section{MEASUREMENT STRATEGY}

Meeting the major scientific objectives of Leg 168 will require quantitatively accurate documentation of rock properties and of lateral and vertical thermal, pressure, and geochemical gradients in pore waters of the sediments and upper basement. Elucidation of these properties and gradients will require the deployment of several specialized tools during

Leg 168, as well as modifications to the standard ODP/JOIDES policies regarding whole- 
round sampling and logging. These modifications are required to achieve the primary objectives of the expedition.

\section{Sediment Temperature Measurements}

Temperature measurements during Leg 168 will be made in the sediments overlying basaltic basement with three tools. The APC temperature tool will be deployed starting with Core 4 and continuing with every APC core until excessive overpull occurs at all sites where APC cores are collected. This includes four first priority Sites (Sites HT-1A, HT-2A, PP-1A, and PP-3A). The ODP water-sampling temperature probe or a third-party (Canadian/German) self-contained sediment temperature probe will be run for temperature measurements in all APC/XCB holes at depths where APC temperature measurements are not possible. These tools also will be run in all RCB holes, as often as every other core on occasion. Actual measurement frequency with all temperature tools will depend on local anticipated requirements or on results obtained during previous deployments.

\section{Interstitial-Water Measurements}

To document the nature, extent, direction, and intensity of fluid flow within the sediments and underlying basement, closely-spaced samples will be required. Interstitial water will be collected by squeezing 5-10-cm-long whole-round samples from every core. Higher resolution sampling (perhaps as frequent as one per section) will be required near the seafloor and immediately above the sediment/basement interface. Additional samples may be collected from split cores. This should result in the collection of approximately 200-250 pore water samples.

\section{Physical Properties Samples}

In order to document the physical nature of alteration and hydrologic properties within the sediment column and the extent of lateral variations in sediment properties, whole-round samples will be collected at several of the APC holes. Four to six samples will be collected at each of the Sites HT-1A, HT-2A, PP-1A, and PP-3A. These samples will be subjected to geotechnical and permeability testing, as well as XRD, index properties, grain-size, and SEM analysis to evaluate the relationships between hydrologic properties and alteration.

Whole-round basement cores may also be required for short-term, nondestructive anelastic stress relaxation tests. If these measurements are done, the samples will be returned to the normal core handling routine within a few days. 


\section{Wireline Logging}

JOIDES policy generally directs that a standard suite of logging instruments be run in all sediment holes deeper than $400 \mathrm{~m}$ and in basement holes with greater than $50 \mathrm{~m}$ of open hole. This standard suite includes a geophysical string, a Formation Microscanner (FMS) string, and a geochemical string. The Quad combination (Quad-combo) geophysical tool string provides measurements of natural gamma activity, sonic velocity, porosity, density, and electrical resistivity. Data from this tool string will aid in characterizing lithology, sediment fabric, degree of lithification, and diagenetic alteration and will aid in defining the location and distribution of possible fluid pathways. Together with core measurements, the sonic velocity and density logs can be used to generate synthetic seismograms, which can tie seismic information directly to the $\log$ and core data. The Formation Microscanner produces oriented, two-dimensional, high-resolution images of the variations in microresistivity around the borehole wall that can be used to distinguish thin beds, sedimentary structures, diagenetic features, and fractures. FMS images can also be used for correlation of coring and logging depth, orientation of cores, and location of cored sections where recovery is less than 100\%. The Geochemical Logging Tool (GLT) provides bulk mineralogy and delineates mineralogical changes downhole. The GLT measures relative concentrations of $\mathrm{Si}, \mathrm{Ca}, \mathrm{Fe}$, $\mathrm{S}, \mathrm{H}$, and $\mathrm{Cl}$, as well as wet weight percentages of $\mathrm{K}, \mathrm{U}$, Th, and Al. Shore-based processing calculates dry-weight percentages of these major rock-forming elements as well as $\mathrm{Gd}$ and $\mathrm{Ti}$.

Within the sediment column, the FMS and geochemical logging tools are expected to provide little information of direct benefit to the scientific objectives of Leg 168. For this reason, and because of time and operational limitations (such as the use of an 11-3/4" APC/XCB bit in one of the logged holes) logging within the holes at Sites PP-1A and PP-4A will most likely be restricted to geophysical tool strings. The FMS may also be run at Site PP-4A, depending on drilling conditions, the time required to core, and the time remaining for additional operations. Basement penetration may be limited to $40 \mathrm{~m}$ per site, with total open-hole length of only $30 \mathrm{~m}$, essentially precluding the use of wireline logs. However, additional basement penetration and associated downhole measurements (including a full suite of Schlumberger logs and packer/flowmeter work), is included in the list of alternative operational plans. Options for additional basement work during Leg 168 will be considered along with options for additional sediment coring and sampling.

\section{Long-Term Borehole Observatories (CORKs)}

CORKs were deployed during ODP Legs 139, 146, and 156. The conceptual and physical 
design of the CORK experiment are detailed in Davis et al. (1992). The CORK system comprises a modified reentry cone, a hydrologic seal that fits inside the throat of the cone, a data logger with sufficient power and memory to record data for several years, a valve mechanism by which the sealed hole can be vented to the overlying ocean, and a sensor cable to monitor formation pressure and temperature as a function of depth. A continuous fluid sampler will also be installed as part of each sensor cable. The samplers will provide a timeseries sample of basement water as the perturbations associated with drilling dissipate.

The CORK deployments during Leg 168 are intended to quantify accurately the temperatures and pressures in uppermost basement that are responsible for vertical and lateral fluid, heat, and solute transport and any resulting gradients in fluid geochemistry. The Leg 168 operations strategy was designed to maximize the chances for four CORK deployments during a single cruise.

\section{REFERENCES}

Alt, J.C., Honnorez, J., Laverne, C., and Emmermann, R., 1986. Hydrothermal alteration of a $1 \mathrm{~km}$ section through the upper oceanic crust: DSDP Hole 504B: mineralogy, chemistry, and evolution of seawater-basalt interactions. J. Geophys. Res., 91:1030910335.

Anderson, R.N., Langseth, M.G., and Sclater, J.G., 1977. The mechanisms of heat transfer through the floor of the Indian Ocean. J. Geophys. Res., 82:3391-3409.

Becker, K., Morin, R.H., and Davis, E.E., 1994. Permeabilities in the Middle Valley hydrothermal system measured with packer and flowmeter experiments. In Mottl, M.J., Davis, E.E., et al., Proc. ODP, Sci. Results, 139: College Station, TX (Ocean Drilling Program), 613-626.

Cande, S.C., and Kent, D.V., 1992. A new geomagnetic polarity time scale for the Late Cretaceous and Cenozoic. J. Geophys. Res., 97:13917-13951.

Currie, R.G., Seemann, D.S., and Riddihough, R.P,1982. Total magnetic field anomaly, offshore British Columbia. Open-File Rep.-Geol. Surv. Can., 828.

Davis, E.E., and Becker, K., 1994. Formation temperatures and pressures in a sedimented rift hydrothermal system: ten months of CORK observations, Holes 857D and 858G.In Mottl, M.J., Davis, E.E., et al., Proc. ODP, Sci. Results, 139: College Station, TX (Ocean Drilling Program), 649-666.

Davis, E.E., and Currie, R.G. 1993. Geophysical observations of the northern Juan de Fuca 
Ridge system: lessons in sea-floor spreading. Can. J. Earth Sci., 30:278-300.

Davis, E.E., Chapman, D.S., Mottl, M.J., Bentkowski, W.J., Dadey, K., Forster, C., Harris, R., Nagihara, S., Rohr, K., Wheat, G., and Whiticar, M., 1992. FlankFlux: an experiment to study the nature of hydrothermal circulation in young oceanic crust. Can. J. Earth Sci., 29:925-952.

Donnelly, T.W., Thompson, G., and Salisbury, M.H., 1980. The chemistry of altered basalts at Site 417, DSDP Leg 51. In Donnelly, T., Francheteau, J., et al., Init. Repts., DSDP, 51, 52, 53 (Pt. 2): Washington (U.S. Govt. Printing Office), 1319-1330.

Fisher, A.T., Becker, K., Narasimhan, T.N., Langseth, M.G., and Mottl, M.J., 1990. Passive, off-axis convection through the southern flank of the Costa Rica rift.J. Geophys. Res., 95:9343-9370.

Fisher, A.T., and Becker, K., 1995. Correlation between seafloor heat flow and basement relief: observational and numerical examples and implications for upper crustal permeability. J. Geophys. Res., 100:12641-12657.

Green, K.E., Von Herzen, R.P., and Williams, D.L. 1981. The Galapagos spreading center at $86^{\circ} \mathrm{W}$ : a detailed geothermal field study.J. Geophys. Res., 86:979-986.

Hartline, B.K., and Lister, C.R.B., 1981. Topographic forcing of supercritical convection in a porous medium such as the oceanic crust. Earth Plan. Sci. Lett., 55:75-86.

Houtz, R., and Ewing, J.R., 1976. Upper crustal structure as a function of plate age. $J$. Geophys. Res., 81:2490-2498.

Jacobson, R.S., 1992. Impact of crustal evolution on changes of the seismic properties of the uppermost oceanic crust. Rev. Geophys., 30:23-42.

Johnson, H.P., and Holmes, M.L., 1989. Evolution in plate tectonics: the Juan de Fuca Ridge. In Winter, E.L., Hussong, D.M., and Decker, R.E. (Eds.), The Eastern Pacific Ocean and Hawaii. Geol. Soc. Am., Geol. of North Am. Ser., N:73-91.

Langseth, M.G., Becker, K., Von Herzen, R.P., and Schultheiss, P., 1992. Heat and fluid flux through sediment on the western flank of the Mid-Atlantic Ridge: a hydrogeological study of North Pond. Geophys. Res. Lett., 19:517-520.

Langseth, M.G., Mottl, M.J., Hobart, M.A., and Fisher, A., 1988. The distribution of geothermal and geochemical gradients near Site 501/504: implications for hydrothermal circulation in the oceanic crust. In: Becker, K., Sakai, H., et al., Proc. ODP, Init. Repts. 111: College Station, TX (Ocean Drilling Program), 23-32.

Lister, C.R.B., 1977. Estimators for heat flow and deep rock properties based on boundary layer models. Tectonophysics, 41:157-171.

Lister, C.R.B., 1972. On the thermal balance of a mid-ocean ridge. Geophys. J. Roy. Astr. 
Soc., 26:515-535.

Lowell, R.P., 1980. Topographically driven subcritical hydrothermal convection in the oceanic crust. Earth Plan. Sci. Lett., 49:21-28.

Mottl, M.J., 1989. Hydrothermal convection, reaction, and diffusion in sediments on the Costa Rica Rift flank: pore-water evidence from ODP Sites 677 and 678. In Becker, K., Sakai, H., et al., Proc. ODP, Sci. Results, 111: College Station, TX (Ocean Drilling Program), 195-213.

Mottl, M.J., and Wheat, C.G., 1994. Hydrothermal circulation through mid-ocean ridge flanks: heat and magnesium fluxes. Geochim. Cosmochim. Acta, 58:2225-2237.

Mottl, M.J., Wheat, C.J., Malahoff, A., Davis, E.E., and Baker, E.T., 1993. Hydrothermal venting through outcrops on 3.5 Ma-old crust, eastern flank of the Juan de Fuca Ridge near $48^{\circ} \mathrm{N}$ : FlankFlux 92. Eos Trans. AGU, 74: 241.

Purdy, G.M., 1987. New observations of the shallow seismic structure of young oceanic crust, J. Geophys. Res., 92:9351-9362.

Rohr, K., 1994. Increase of seismic velocities in upper oceanic crust and hydrothermal circulation in the Juan de Fuca plate. Geophys. Res. Lett., 21:2163-2166.

Sclater, J.G., Crowe, J., and Anderson, R.N., 1976. On the reliability of oceanic heat flow averages. J. Geophys. Res., 81:2997-3006.

Spell, T.L., and McDougall, I., 1992. Revisions to the age of the Brunhes-Matuyama boundary and the Pleistocene geomagnetic polarity time scale. Geophys. Res. Lett., 19:1181-1184.

Thomson, R.E., Davis, E.E., and Burd, B.J., 1995. Hydrothermal venting and geothermal heating in Cascadia Basin. J. Geophys. Res., 100:6121-6142.

Von Herzen, R.P., Detrick, R.S., Crough, T., Epp, D., and Fehn, U., 1982. Thermal origin of the Hawaiian Swell: heat flow evidence and thermal models. J. Geophys. Res., $87: 6711$.

Wheat, C.G., and Mottl, M.J., 1994. Hydrothermal circulation, Juan de Fuca Ridge eastern flank: factors controlling basement water composition.J. Geophys. Res., 99: 3067-3080.

Williams, D.L., and Von Herzen, R.P., 1974. Heat loss from the Earth: new estimate. Geology, 2:327.

Wilkens, R.H., Freyer, G.J.,and Karsten, J., 1991. Evolution of porosity and seismic structure of upper oceanic crust: importance of aspect ratios. J. Geophys. Res., 96:17981-17995. 
TABLE 1. SITE OPERATIONS SUMMARY (Priority 1)

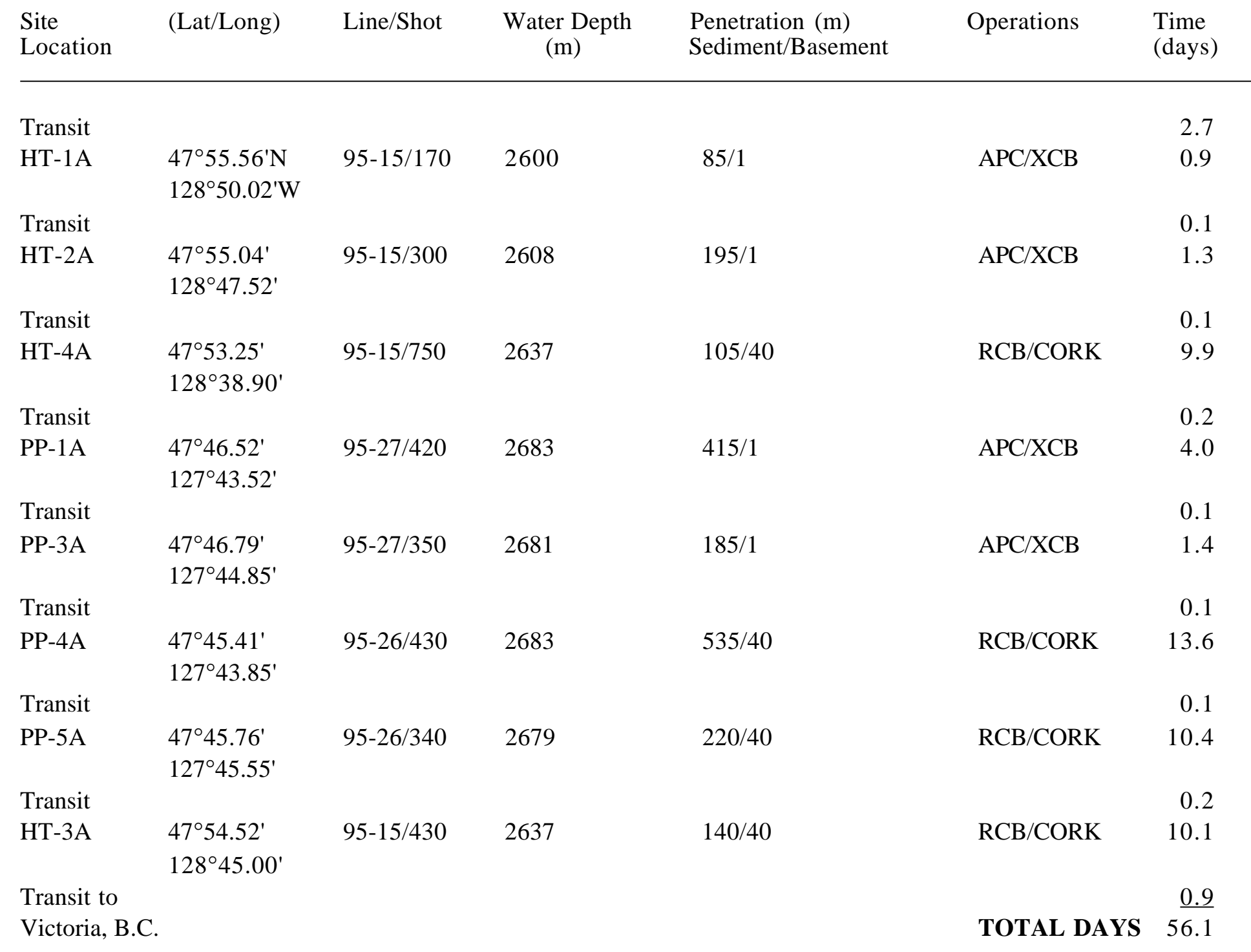

Note: These holes are listed according to the planned order of drilling. 
TABLE 2. SITE OPERATIONS SUMMARY (Priority 2)

\begin{tabular}{|c|c|c|c|c|c|c|}
\hline $\begin{array}{l}\text { Site } \\
\text { Location }\end{array}$ & (Lat/Long) & Line/Shot & $\begin{array}{l}\text { Water Depth } \\
\text { (m) }\end{array}$ & $\begin{array}{l}\text { Penetration }(\mathrm{m}) \\
\text { Sediment/Basement }\end{array}$ & Operations & $\begin{array}{l}\text { Time } \\
\text { (Days) }\end{array}$ \\
\hline PP-2A & $\begin{array}{l}47^{\circ} 46.71^{\prime} \\
127^{\circ} 44.47^{\prime}\end{array}$ & $95-27 / 370$ & 2682 & $265 / 1$ & $\mathrm{APC} / \mathrm{XCB}$ & 2.3 \\
\hline PP-5A & $\begin{array}{l}47^{\circ} 45.76^{\prime} \\
127^{\circ} 45.55^{\prime}\end{array}$ & $95-26 / 340$ & 2679 & $0 / 100+$ & $\begin{array}{l}\text { Deepen into } \\
\text { Basement }\end{array}$ & 2.8 \\
\hline PP-6A & $\begin{array}{l}47^{\circ} 42.61^{\prime} \\
127^{\circ} 47.18^{\prime}\end{array}$ & $95-23 b / 70$ & 2618 & $0 / 100$ & $\mathrm{RCB}$ & 3.0 \\
\hline $\begin{array}{l}\text { PP-7A } \\
-8 \mathrm{~A} / 9 \mathrm{~A}\end{array}$ & $\begin{array}{l}47^{\circ} 42.63^{\prime} \\
127^{\circ} 47.37^{\prime}\end{array}$ & $95-23 b / 60$ & 2687 & $40,95, \& 135$ & APC/XCB & 2.2 \\
\hline PP-10A & $\begin{array}{l}47^{\circ} 44.68^{\prime} \\
127^{\circ} 45.97^{\prime}\end{array}$ & $95-32 / 285$ & 2683 & $275 / 1$ & $\mathrm{APC} / \mathrm{XCB}$ & 2.4 \\
\hline LH-2A & $\begin{array}{l}47^{\circ} 46.23^{\prime} \\
128^{\circ} 04.62^{\prime}\end{array}$ & $95-23 a / 615$ & 2662 & $280 / 1$ & $\mathrm{APC} / \mathrm{XCB}$ & 2.3 \\
\hline
\end{tabular}

Note: These holes are listed with no internal priority implied; the order of drilling will depend on earlier results of the leg. Basement penetration listed for APC/XCB drilling $(1 \mathrm{~m})$ indicates minor recovery. 


\section{FIGURES}

Figure 1. Location map for Leg 168 drilling operations, indicating area in Figures 2 and 3.

Figure 2. Bathymetry of the Juan de Fuca Ridge and ridge flank where Leg 168 proposed sites are located.

Figure 3. Magnetic anomalies (from Currie et al., 1982) and inferred crustal ages (from Cande and Kent, 1992; Spell and McDougal, 1992) shown for the area in Figure 2.

Figure 4. Seismic reflection and co-located heat-flow profiles crossing the Hydrothermal Transition drilling sites.

Figure 5. Heat flow, basement surface temperatures, and seismic velocities along the Hydrothermal Transition transect. Values are plotted relative to the distance from the Juan de Fuca Ridge axis. The location of the sharp transition from sediment-free to sediment-covered igneous crust is shown as a vertical line.

Figure 6A. Seismic reflection and co-located heat-flow profile crossing the buried basement ridge where Permeable Penetrators proposed drilling Sites PP-1A-PP-3A are located (all sites without the letter "A" label on the figures are the same sites with the letter dicussed in the text). The profile crosses the ridge in a direction perpendicular to strike and is ordered from north to south.

Figure 6B. Seismic reflection and co-located heat-flow profile crossing the buried basement ridge where Permeable Penetrators proposed drilling Sites PP-4A and PP-5A are located. The profile crosses the ridge in a direction perpendicular to strike, and is ordered from north to south.

Figure 6C. Seismic reflection and co-located heat-flow profile crossing the buried basement ridge where Permeable Penetrators proposed drilling Site PP-10A is located. The profile crosses the ridge in a direction perpendicular to strike, and is ordered from north to south.

Figure 7. Seismic reflection and co-located heat-flow profiles crossing the basement outcrop where proposed Sites PP-6A-PP-9A are located. 
Figure 8. Bathymetry of the area of the Permeable Penetrators drilling sites, showing the location of three small basement edifices above the turbidite abyssal plain.

Figure 9. Seismic reflection profile crossing the Lithospheric Heat Flow proposed drilling site. 




Figure 1 


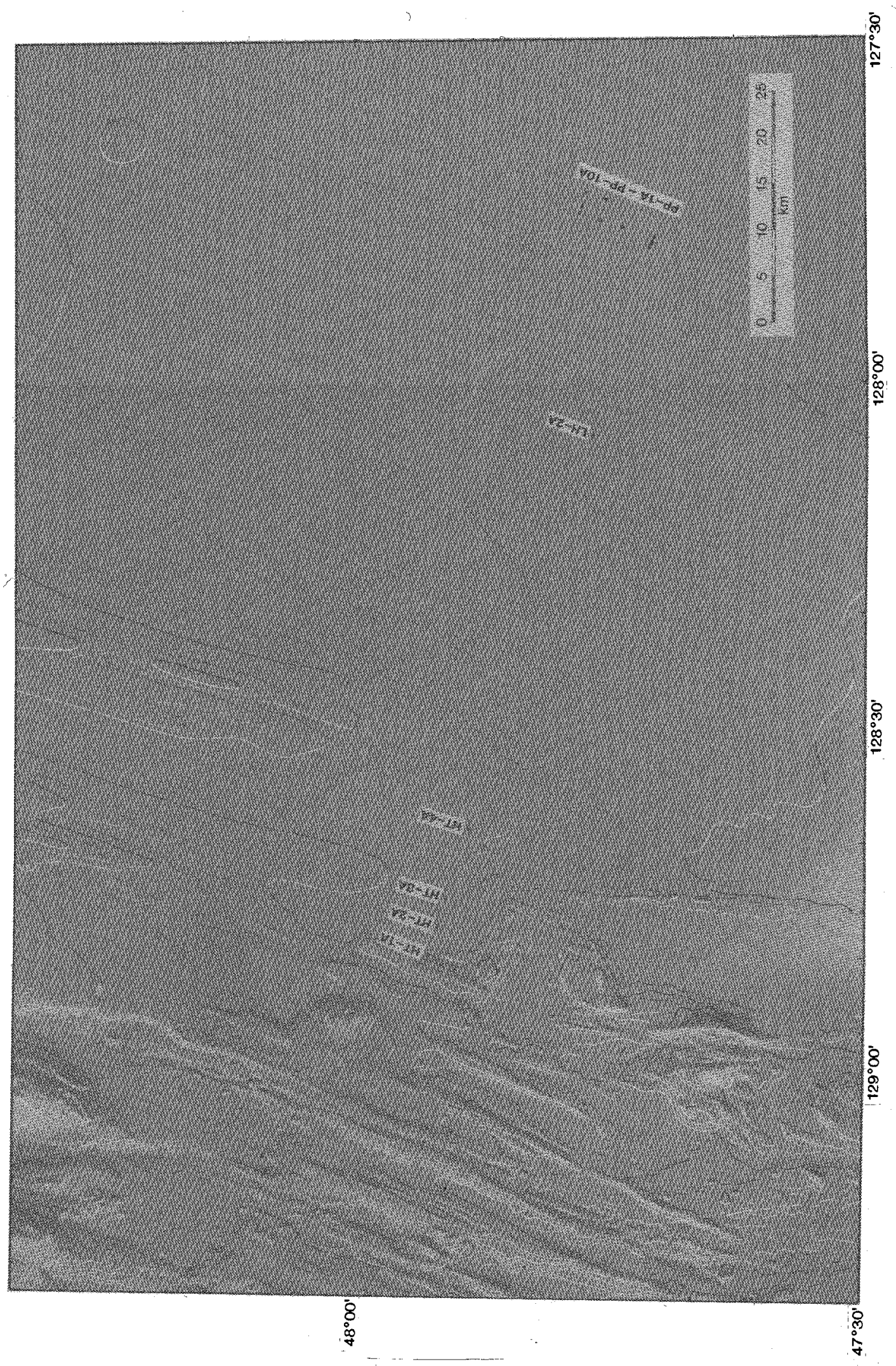

Figure 2 




Figure 3 


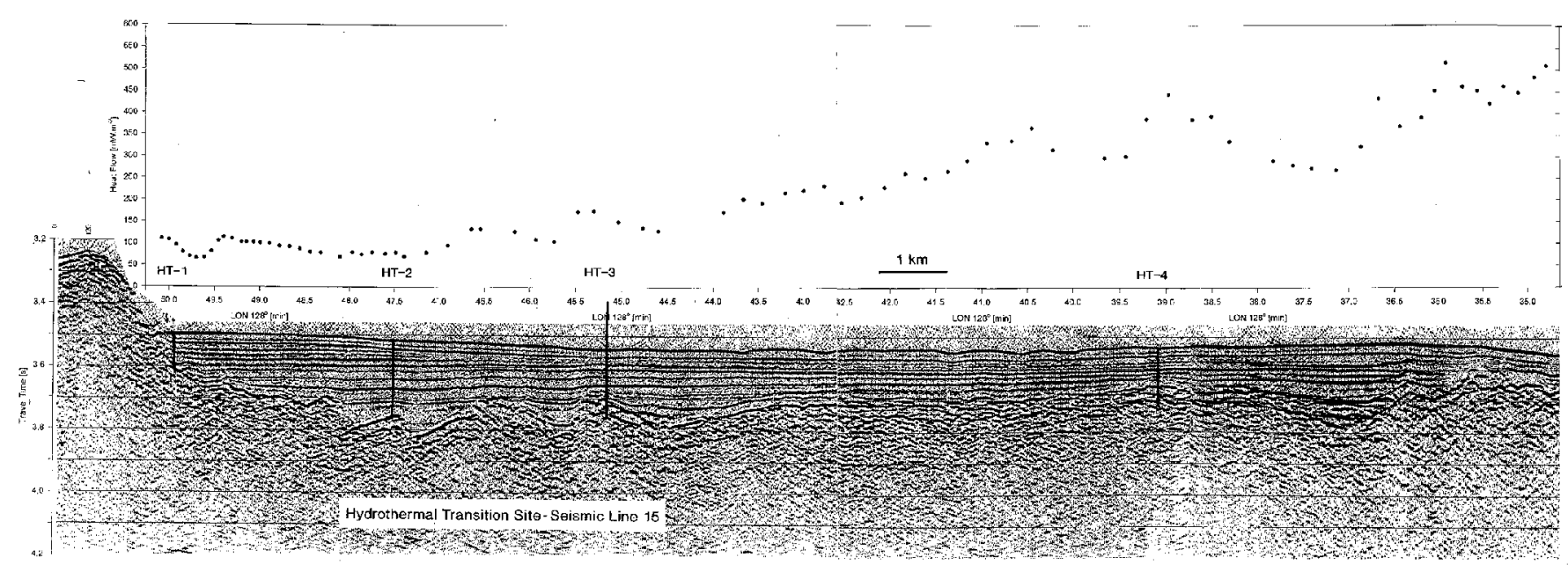



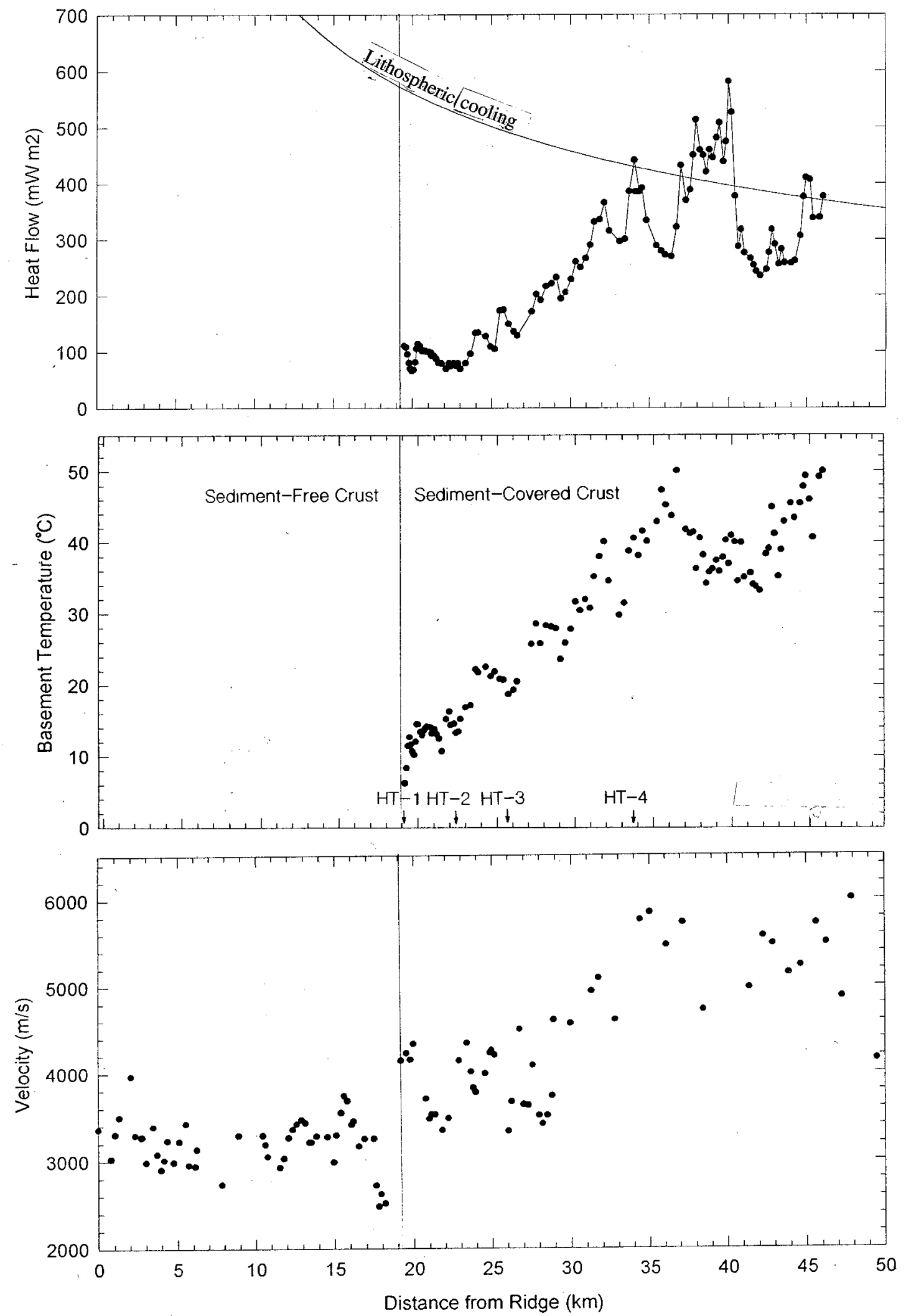

Figure 5 


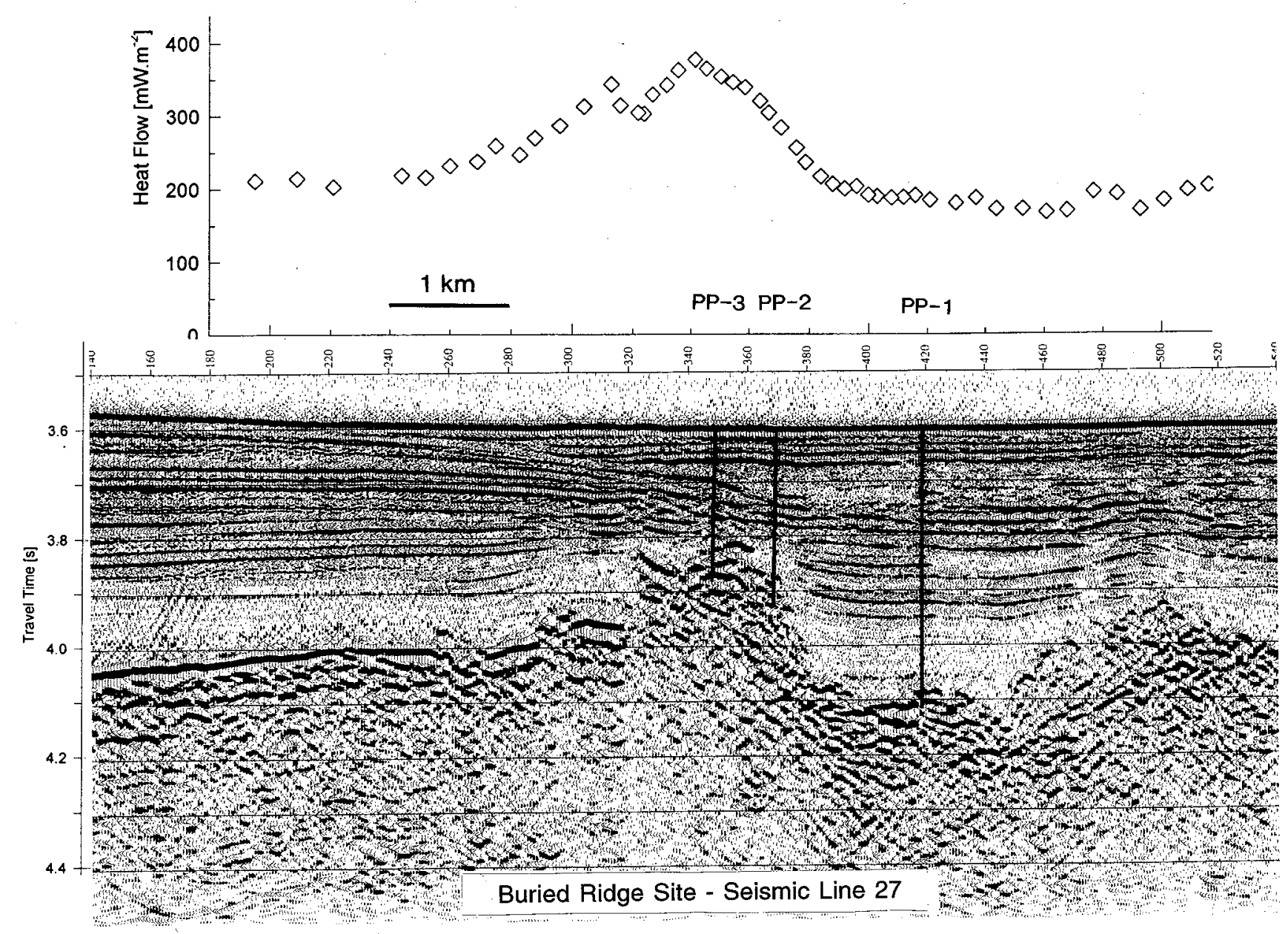




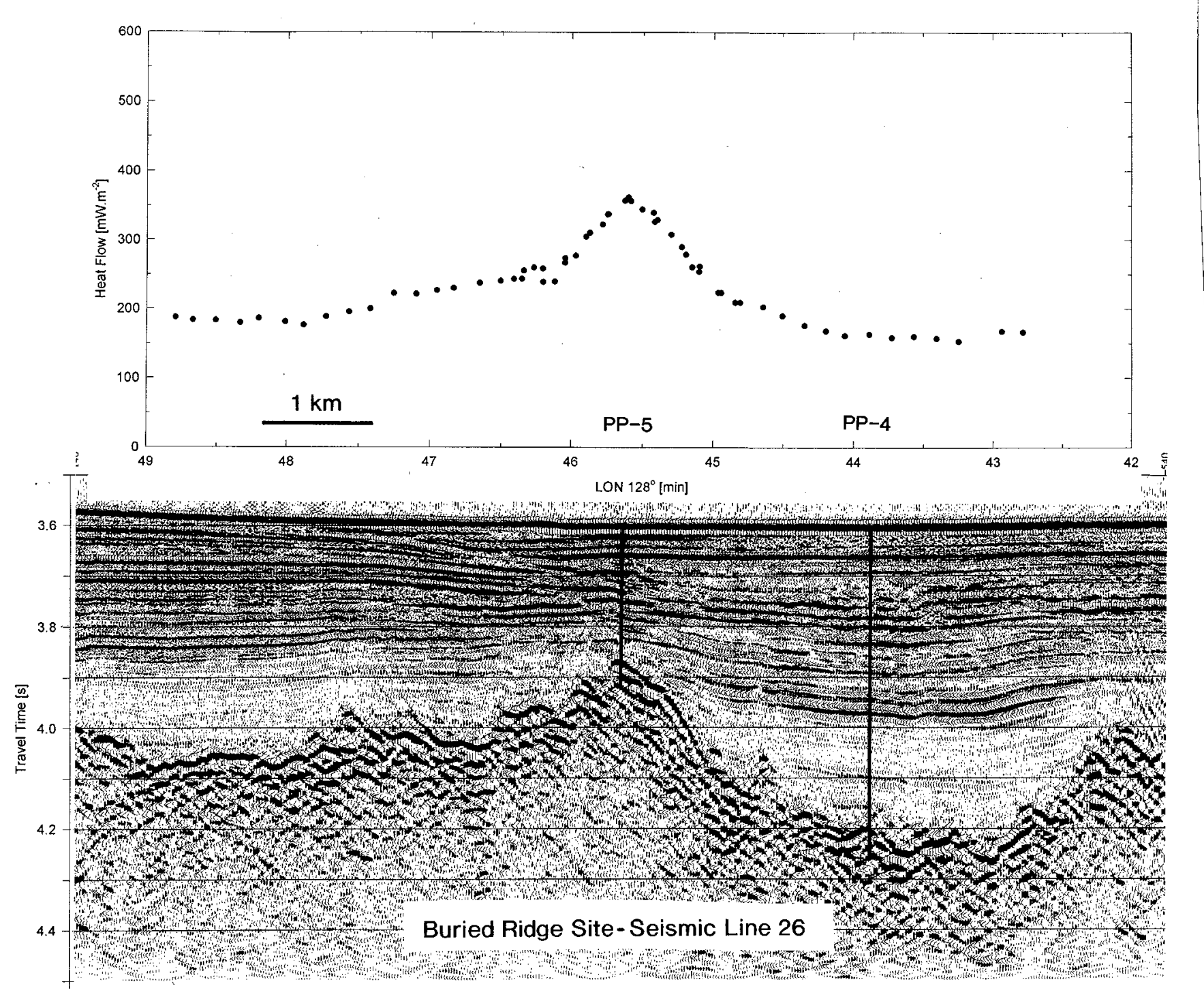




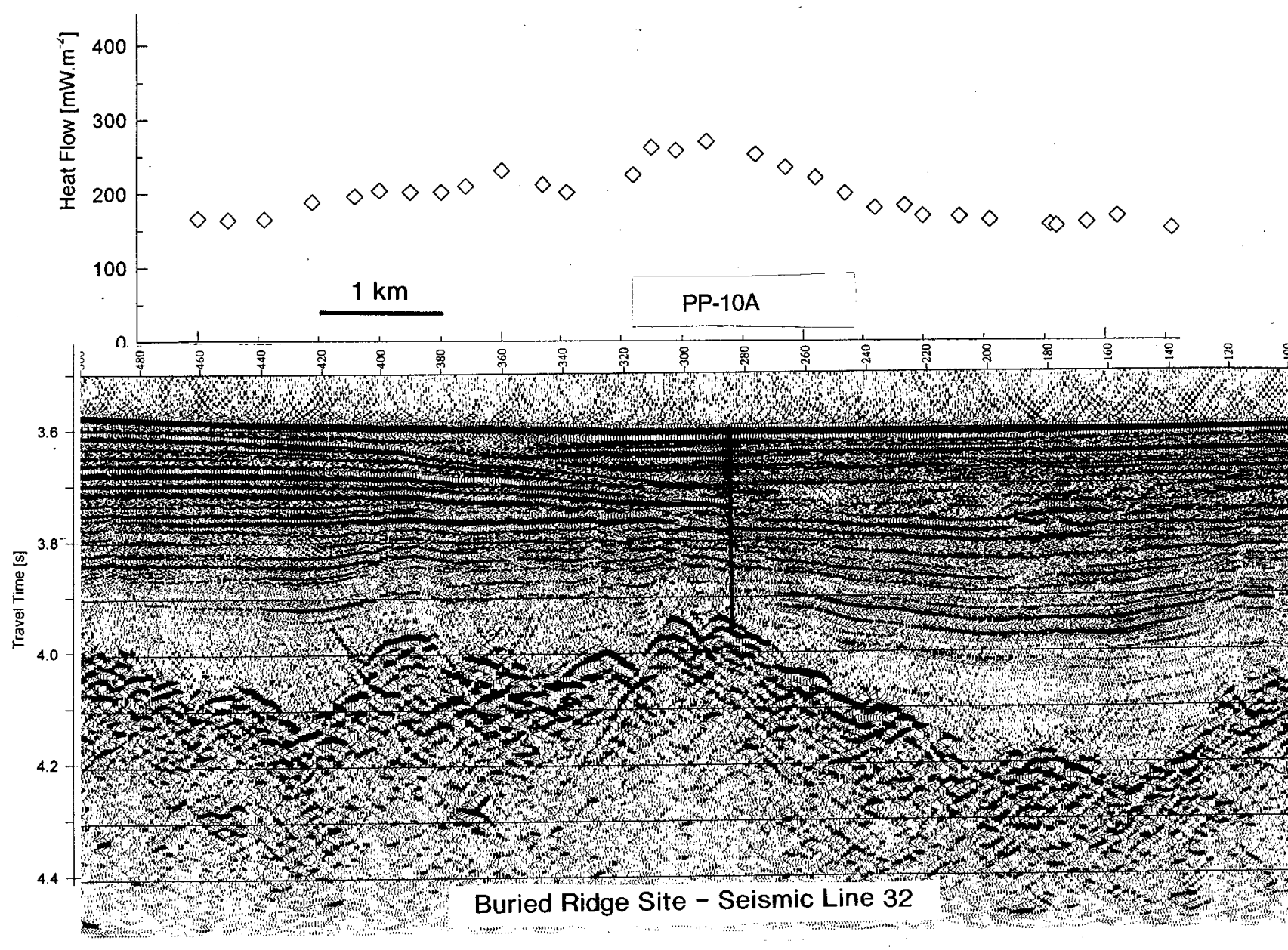




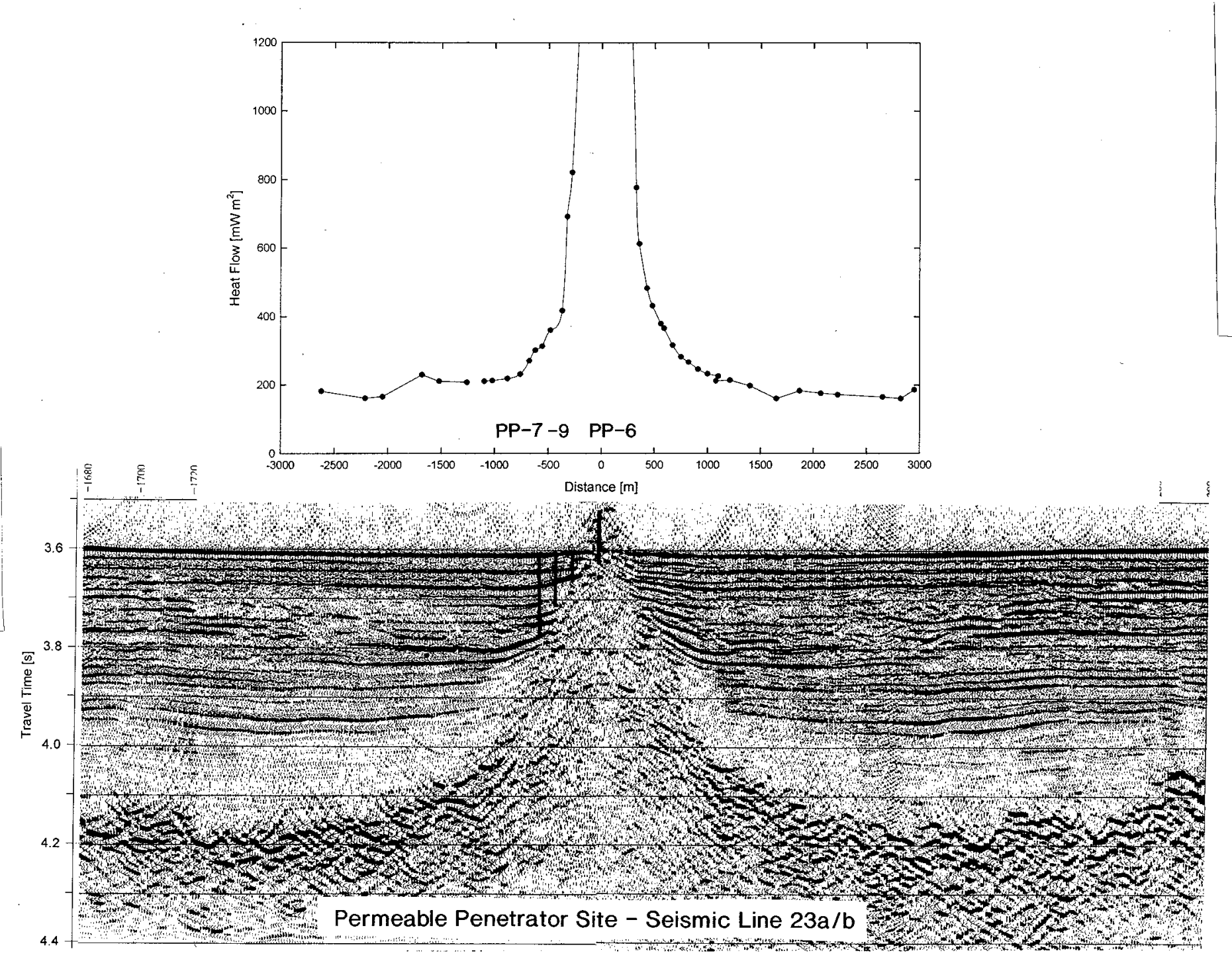




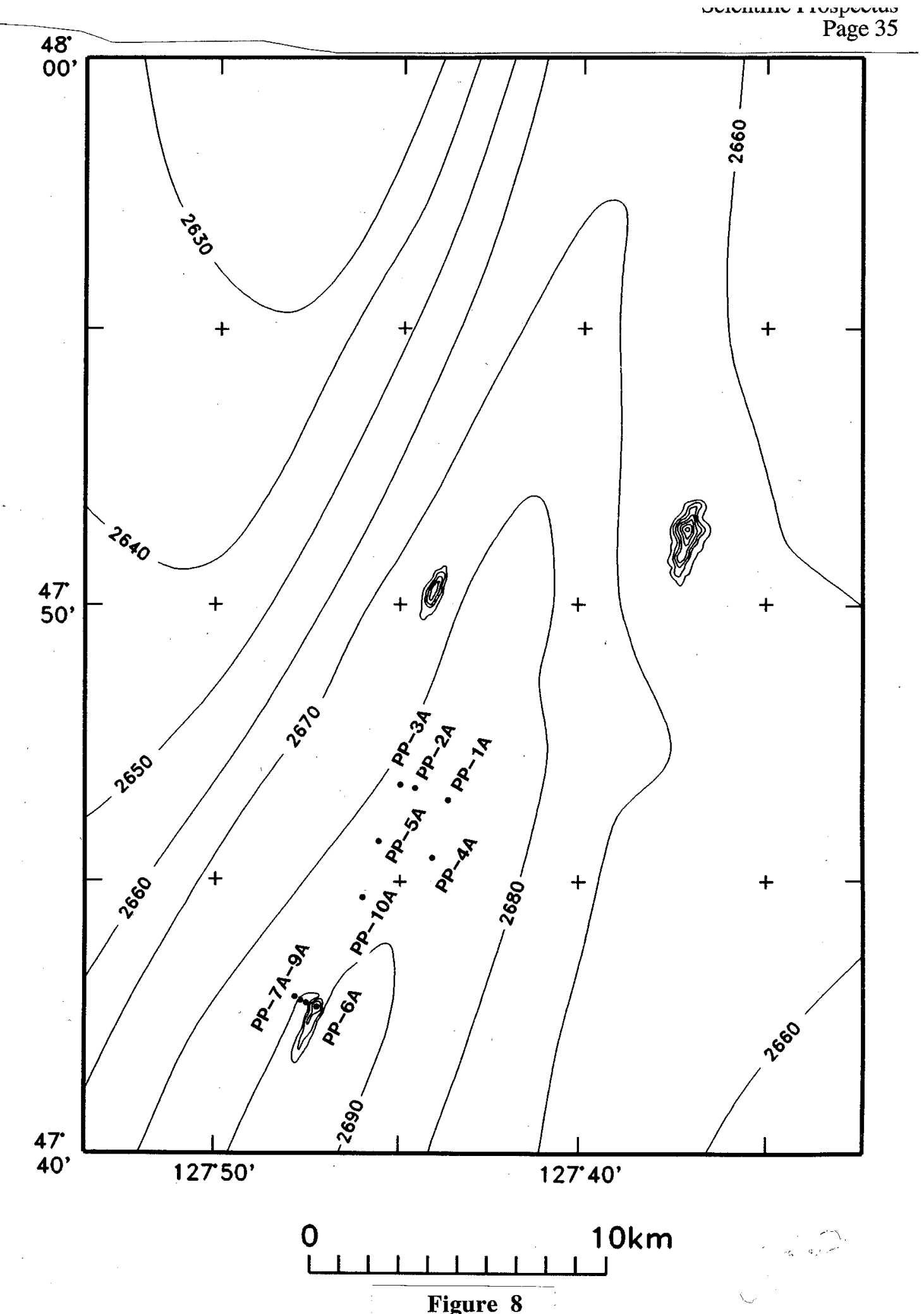









\section{APPENDICES}

Appendix 1A. Seismic track lines across the Hydrothermal Transition sites.

Appendix 1B. Seismic track lines across the Permeable Penetrator sites.

Appendix 1C. Seismic track lines across the Lithospheric Heat Flow site. 


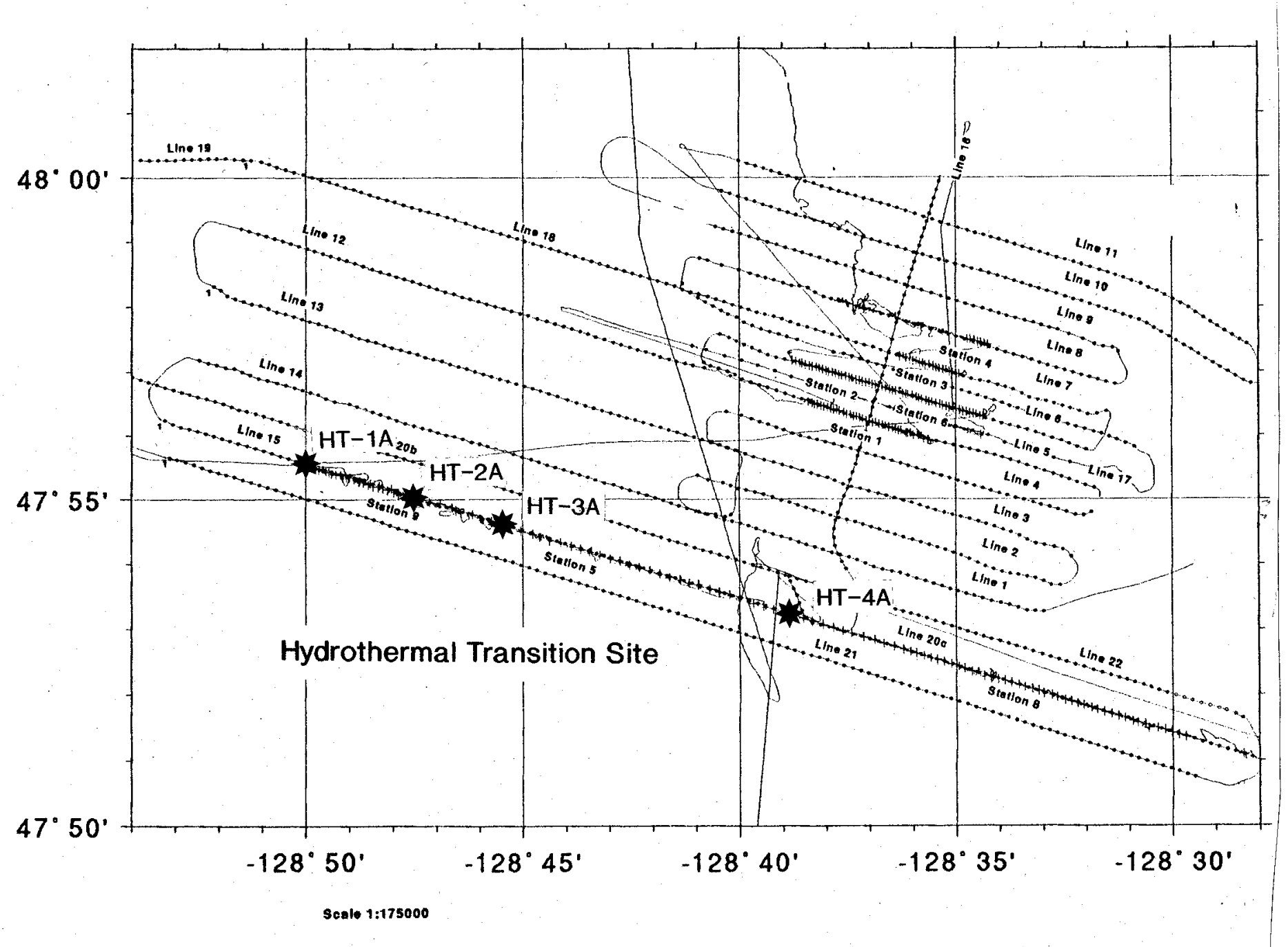









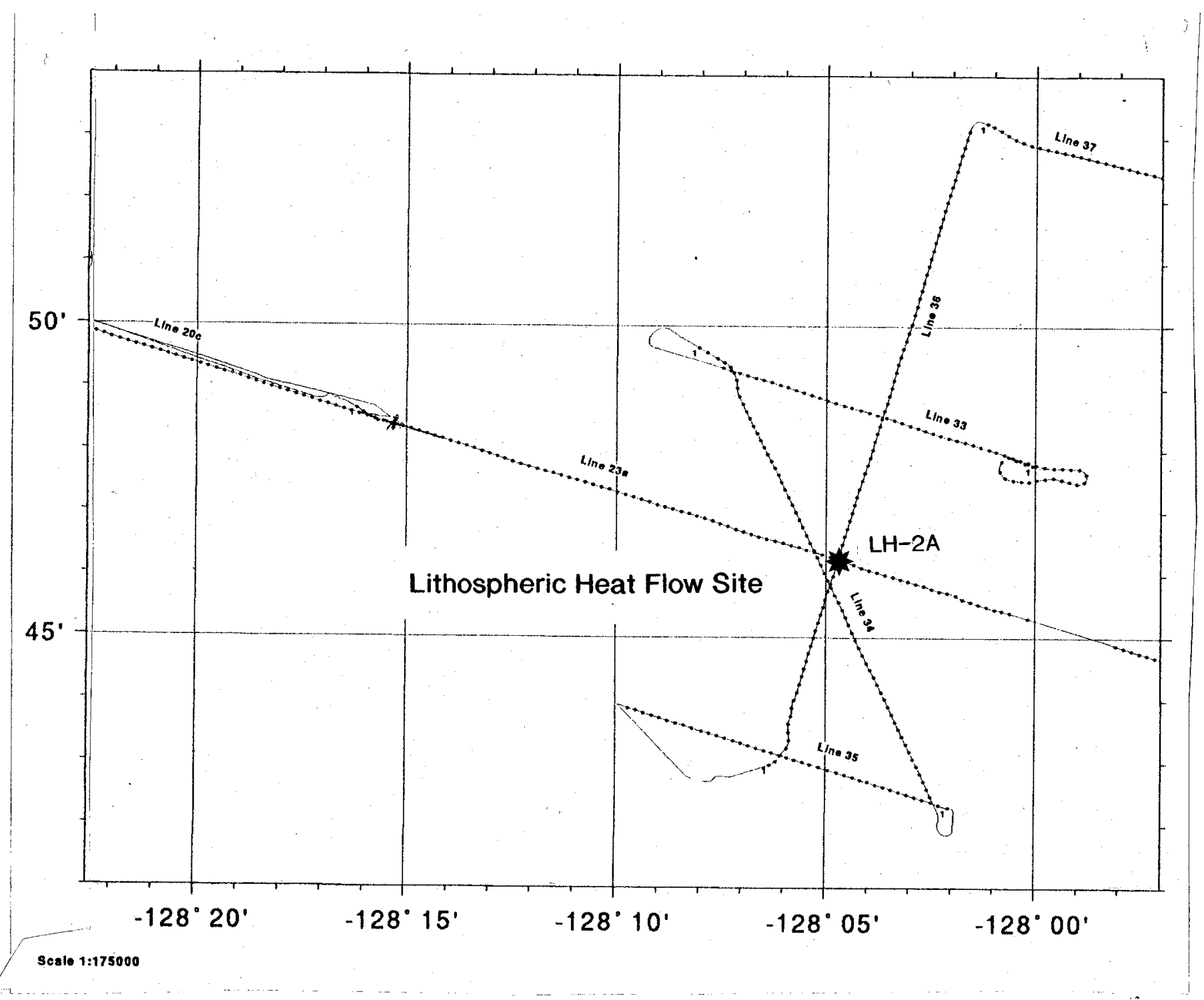




\section{PROPOSED DRILL SITES}

Site: HT-1A

\section{Priority: 1}

Position: $47^{\circ} 55.56^{\prime} \mathrm{N} ; 128^{\circ} 50.02^{\prime} \mathrm{W}$

Water Depth: $2600 \mathrm{~m}$

Sediment Thickness: $85 \mathrm{~m}$

Total Penetration: $85 \mathrm{mbsf}$ (stop at first basement recovery)

Seismic Coverage: Line 95-15, S.P. 170 (Fig. 4, Appendix 1A)

Objectives: The Hydrothermal Transition site comprises a suite of four holes spanning a transition from open to sediment-sealed hydrothermal circulation in the oceanic crust. Holes are sited from $200 \mathrm{~m}$ to about $20 \mathrm{~km}$ away from the nearest basement outcrop. Heat flow across the transect increases from about $15 \%$ to more than $80 \%$ of expected lithospheric values; upper basement temperatures increase from a few degrees to more than $40^{\circ} \mathrm{C}$; hydrothermal fluid composition changes from normal to altered seawater; upper crustal seismic velocities increase from approximately 3.5 to more than $5.5 \mathrm{~km} / \mathrm{s}$. This hole is located in the youngest crust of the transect, and only a few hundred meters from outcropping basement. Basement temperature is expected to be less than $10^{\circ} \mathrm{C}$.

\section{Drilling Program: APC/XCB (if necessary)}

Logging and Downhole: APC temperature every core

Nature of Rock Anticipated: Turbidite sediments, unaltered basalt 


\section{Site: HT-2A}

\section{Priority: 1}

Position: $47^{\circ} 55.04^{\prime} \mathrm{N} ; 128^{\circ} 47.52^{\prime} \mathrm{W}$

Water Depth: $2608 \mathrm{~m}$

Sediment Thickness: $195 \mathrm{~m}$

Total Penetration: $195 \mathrm{mbsf}$ (stop at first basement recovery)

Seismic Coverage: Line 95-15, SP 300 (Fig. 4, Appendix 1A)

Objectives: The Hydrothermal Transition site comprises a suite of four holes spanning a transition from open to sediment-sealed hydrothermal circulation. Holes are sited from $200 \mathrm{~m}$ to $20 \mathrm{~km}$ away from the nearest basement outcrop. Heat flow across the transect increases from about $15 \%$ to more than $80 \%$ of expected lithospheric values; upper basement temperatures increase from a few degrees to more than $40^{\circ} \mathrm{C}$; hydrothermal fluid composition changes from normal to altered seawater; upper crustal seismic velocities increase from approximately 3.5 to more than $5.5 \mathrm{~km} / \mathrm{s}$. This hole is anticipated to find basement at roughly $15^{\circ} \mathrm{C}$.

Drilling Program: APC/XCB

Logging and Downhole: APC temperature at up to every core; five temperature probe trips

Nature of Rock Anticipated: Turbidite sediments, weakly altered basalt 
Site: HT-3A

Priority: 1

Position: $47^{\circ} 54.52^{\prime} \mathrm{N} ; 128^{\circ} 45.00^{\prime} \mathrm{W}$

Water Depth: $2637 \mathrm{~m}$

Sediment Thickness: $140 \mathrm{~m}$

Total Penetration: $180 \mathrm{mbsf}$

Seismic Coverage: Line 95-15, SP 430 (Fig. 4, Appendix 1A)

Objectives: The Hydrothermal Transition site comprises a suite of four holes spanning a transition from open to sediment-sealed hydrothermal circulation. Holes are sited from $200 \mathrm{~m}$ to $20 \mathrm{~km}$ away from the nearest basement outcrop. Heat flow across the transect increases from about $15 \%$ to more than $80 \%$ of expected lithospheric values; upper basement temperatures increase from a few degrees to more than $40^{\circ} \mathrm{C}$; hydrothermal fluid composition changes from normal to altered seawater; upper crustal seismic velocities increase from approximately 3.5 to more than $5.5 \mathrm{~km} / \mathrm{s}$. This reentry hole will intersect basement at approximately $20^{\circ} \mathrm{C}$ and will be completed with a CORK installation.

Drilling Program: RCB only (two trips, both through reentry cone), with approximately 40 $\mathrm{m}$ of basement penetration. Casing will be set after initial RCB drilling reaches first competent basement.

Logging and Downhole: Approximately five temperature probe trips, packer/flowmeter testing, and CORK installation

Nature of Rock Anticipated: Turbidite sediments; weakly altered basalt 
Site: HT-4A

\section{Priority: 1}

Position: $47^{\circ} 53.25^{\prime} \mathrm{N} ; 128^{\circ} 38.90^{\prime} \mathrm{W}$

Water Depth: $2637 \mathrm{~m}$

Sediment Thickness: $95 \mathrm{~m}$

Total Penetration: $145 \mathrm{mbsf}$

Seismic Coverage: Line 95-15, SP 750 (Fig. 4, Appendix 1A)

Objectives: The Hydrothermal Transition site comprises a suite of four holes spanning a transition from open to sediment-sealed hydrothermal circulation. Holes are sited from $200 \mathrm{~m}$ to $20 \mathrm{~km}$ away from the nearest basement outcrop. Heat flow across the transect increases from about $15 \%$ to more than $80 \%$ of expected lithospheric values; upper basement temperatures increase from a few degrees to more than $40^{\circ} \mathrm{C}$; hydrothermal fluid composition changes from normal to altered seawater; upper crustal seismic velocities increase from approximately 3.5 to more than $5.5 \mathrm{~km} / \mathrm{s}$. This site will intersect basement where seafloor heat flow is about $80 \%$ of the total expected from conductive lithospheric cooling and seismic velocity has increased to more than $5 \mathrm{~km} / \mathrm{s}$. Basement temperature is expected to be about $40^{\circ} \mathrm{C}$. Together with Site HT-3A, this CORK site will permit determination of the lateral pressure gradient away from the region of outcropping basement.

Drilling Program: RCB only (two trips, both through reentry cone), with approximately 40 $\mathrm{m}$ of basement penetration. Casing will be set after initial RCB drilling reaches first competent basement.

Logging and Downhole: Approximately four temperature probe trips, packer/flowmeter testing, CORK installation

Nature of Rock Anticipated: Turbidite sediments; mostly altered basalt 
Site: PP-1A

Priority: 1

Position: $47^{\circ} 46.52^{\prime} \mathrm{N} ; 127^{\circ} 43.52^{\prime} \mathrm{W}$

Water Depth: $2683 \mathrm{~m}$

Sediment Thickness: $415 \mathrm{~m}$

Total Penetration: 415 mbsf (stop at first basement penetration)

Seismic Coverage: Line 95-27, SP 420 (Fig. 6A, Appendix 1B)

Objectives: At the Permeable Penetrators site relatively rugged relief of the igneous crust is buried by sediment everywhere, except at three small volcanic edifices where fluids vent through the seafloor. Holes spanning the primary basement relief will allow determination of the lateral thermal and chemical gradients in the upper oceanic crust as well as the buoyancy forces that drive fluid flow. Holes will also extend the overall drilling transect to $3.5 \mathrm{Ma}$. This hole is situated in a fully buried basement valley and will allow detailed sampling of the sediment section.

Drilling Program: APC/XCB

Logging and Downhole: APC temperature measurements at every or every other core, approximately six temperature probe trips, Quad-combo logging run

Nature of Rock Anticipated: Turbidite sediments, altered basalt 


\section{Site: PP-2A}

Priority: 2

Position: $47^{\circ} 46.71^{\prime} \mathrm{N} ; 127^{\circ} 44.47^{\prime} \mathrm{W}$

Water Depth: $2682 \mathrm{~m}$

Sediment Thickness: $265 \mathrm{~m}$

Total Penetration: 265 mbsf (stop at first basement penetration)

Seismic Coverage: Line 95-27, SP 370 (Fig. 6A, Appendix 1B)

Objectives: At the Permeable Penetrators site relatively rugged relief of the igneous crust is buried by sediment everywhere, except at three small volcanic edifices where fluids vent through the seafloor. Holes spanning the primary basement relief will allow determination of the lateral thermal and chemical gradients in the upper igneous crust, and the buoyancy forces that drive fluid flow. The holes will also extend the overall drilling transect to 3.5 Ma.

\section{Drilling Program: APC/XCB}

Logging and Downhole: APC temperature measurements at every or every other core, approximately six temperature probe trips

Nature of Rock Anticipated: Turbidite sediments, altered basalt 
Site: PP-3A

Priority: 1

Position: $47^{\circ} 46.79^{\prime} \mathrm{N} ; 127^{\circ} 44.85^{\prime} \mathrm{W}$

Water Depth: $2681 \mathrm{~m}$

Sediment Thickness: $185 \mathrm{~m}$

Total Penetration: $185 \mathrm{mbsf}$ (stop at first basement recovery).

Seismic Coverage: Line 95-27, SP 350 (Fig. 6A, Appendix 1B)

Objectives: At the Permeable Penetrators site relatively rugged relief of the igneous crust is buried by sediment everywhere, except at three small volcanic edifices where fluids vent through the seafloor. Holes spanning the primary basement relief will allow determination of the lateral thermal and chemical gradients in the upper igneous crust, and the buoyancy forces that drive fluid flow. The holes will also extend the overall drilling transect to 3.5 Ma. This hole is located at the summit of the buried basement ridge and with Sites PP-1A and PP-2A completes the coring transect from the valley to the ridge.

\section{Drilling Program: APC/XCB}

Logging and Downhole: APC temperature measurements at every or every other core, approximately five temperature probe trips

Nature of Rock Anticipated: Turbidite sediments, altered basalt 
Site: PP-4A

Priority: 1

Position: $47^{\circ} 45.41^{\prime} \mathrm{N} ; 127^{\circ} 43.85^{\prime} \mathrm{W}$

Water Depth: $2683 \mathrm{~m}$

Sediment Thickness: $565 \mathrm{~m}$

Total Penetration: $575 \mathrm{mbsf}$

Seismic Coverage: Line 95-26, SP 430 (Fig. 6B, Appendix 1B)

Objectives: At the Permeable Penetrators site relatively rugged relief of the igneous crust is buried by sediment everywhere, except at three small volcanic edifices where fluids vent through the seafloor. Holes spanning the primary basement relief will allow determination of the lateral thermal and chemical gradients in the upper igneous crust, and the buoyancy forces that drive fluid flow. The holes will also extend the overall drilling transect to 3.5 Ma. This CORK reentry hole is situated in a structurally similar location to Site PP-1A; along with those made at Site PP-5A, observations will allow the degree of thermal and chemical homogeneity of basement fluids and the pressure gradient driving fluid flow to be determined.

Drilling Program: RCB only, with approximately $40 \mathrm{~m}$ of basement penetration

Logging and Downhole: Approximately six temperature probe trips, packer/flowmeter testing, Quad-combo logging run, CORK installation

Nature of Rock Anticipated: Turbidite sediments, altered basalt 


\section{Site: PP-5A}

\section{Priority: 1}

Position: $47^{\circ} 45.76^{\prime} \mathrm{N} ; 127^{\circ} 45.55^{\prime} \mathrm{W}$

Water Depth: $2679 \mathrm{~m}$

Sediment Thickness: $230 \mathrm{~m}$

Total Penetration: $260 \mathrm{mbsf}$ (with option for deepening)

Seismic Coverage: Line 95-26, SP 340 (Fig. 6B, Appendix 1B)

Objectives: At the Permeable Penetrators site relatively rugged relief of the igneous crust is buried by sediment everywhere, except at three small volcanic edifices where fluids vent through the seafloor. Holes spanning the primary basement relief will allow the buoyancy forces that drive fluid flow to be determined; holes into one of the permeable basement outcrops will allow the rate and history of discharge to be determined. The holes will extend the overall drilling transect to $3.5 \mathrm{Ma}$. This CORK reentry hole is situated in a structurally similar location to Site PP-3A; together with those made at Site PP-4A, these observations will allow determination of the degree of thermal and chemical homogeneity of basement fluids and the pressure gradient driving fluid flow.

Drilling Program: RCB only with approximately $40 \mathrm{~m}$ of basement penetration, but it may be selected for deeper penetration

Logging and Downhole: Approximately five temperature probe trips, packer/flowmeter testing, Quad-combo logging run, possible FMS and GLT logging runs, CORK installation

Nature of Rock Anticipated: Turbidite sediments; altered basement 
Site: PP-6A

Priority: 2

Position: $47^{\circ} 42.61^{\prime} \mathrm{N} ; 127^{\circ} 47.18^{\prime} \mathrm{W}$

Water Depth: $2618 \mathrm{~m}$

Sediment Thickness: $0 \mathrm{~m}$

Total Penetration: $100 \mathrm{mbsf}$

Seismic Coverage: Line 95-23b, SP 70 (Fig. 7, Appendix 1B)

Objectives: At the Permeable Penetrators site relatively rugged relief of the igneous crust is buried by sediment everywhere, except at three small volcanic edifices where fluids vent through the seafloor. Holes spanning the primary basement relief will allow the buoyancy forces that drive fluid flow to be determined; holes into one of the permeable basement outcrops will allow the rate and history of discharge to be determined. The holes will extend the overall drilling transect to 3.5 Ma. This hole would be drilled directly into the summit of a nearly fully buried basement edifice where a long history of basement fluid venting maybe recorded. Venting is known to be active.

Drilling Program: RCB (bare-rock spud-in)

Logging and Downhole: Possibly one temperature probe trip

Nature of Rock Anticipated: Highly altered basalt, hydrothermal precipitates 
Site: PP-7A, PP-8A, PP-9A transect

Priority: 2

Position: $47^{\circ} 42.63^{\prime} \mathrm{N} ; 127^{\circ} 47.37^{\prime} \mathrm{W}$

Water Depth: $2687 \mathrm{~m}$

Sediment Thickness: 40, 95, $135 \mathrm{~m}$

Total Penetration: 40, 95, $135 \mathrm{mbsf}$ (some basement penetration if possible)

Seismic Coverage: Line 95-23b, SP 60, 55, and 50 (Fig. 7, Appendix 1B)

Objectives: At the Permeable Penetrators site relatively rugged relief of the igneous crust is buried by sediment everywhere, except at three small volcanic edifices where fluids vent through the seafloor. Holes spanning the primary basement relief will allow the buoyancy forces that drive fluid flow to be determined; holes into one of the permeable basement outcrops will allow the rate and history of discharge to be determined. The holes will extend the overall drilling transect to 3.5 Ma. Drilling at this site would address the same objectives as at PP-6A, but the sediment cover will permit drilling if bare-rock spud-in at Site PP-6A is not possible.

Drilling Program: APC/XCB

Logging and Downhole: Frequent APC temperature measurements

Nature of Rock Anticipated: Turbidite sediments, highly altered basalt 
Site: PP-10A

Priority: 2

Position: $47^{\circ} 44.68^{\prime} \mathrm{N} ; 127^{\circ} 45.97^{\prime} \mathrm{W}$

Water Depth: $2683 \mathrm{~m}$

Sediment Thickness: $275 \mathrm{~m}$

Total Penetration: $275 \mathrm{mbsf}$ (stop at first basement recovery)

Seismic Coverage: Line 95-32, SP 285 (Appendix 1B)

Objectives: At the Permeable Penetrators site relatively rugged relief of the igneous crust is buried by sediment everywhere, except at three small volcanic edifices where fluids vent through the seafloor. Holes spanning the primary basement relief will allow the buoyancy forces that drive fluid flow to be determined; holes into one of the permeable basement outcrops will allow the rate and history of discharge to be determined. The holes will extend the overall drilling transect to $3.5 \mathrm{Ma}$. This hole is located above the buried basement ridge along strike from Sites PP-3A and PP-5A. Sediment and pore-fluid sampling at these sites will allow the relationship of sediment thickness to vertical fluid seepage rate to be established.

\section{Drilling Program: APC/XCB}

Logging and Downhole: APC temperature measurements at up to every core, approximately six temperature probe trips

Nature of Rock Anticipated: Turbidite sediments, altered basalt 
Site: LH-2A

Priority: 2

Position: $47^{\circ} 46.23^{\prime} \mathrm{N} ; 128^{\circ} 04.62^{\prime} \mathrm{W}$

Water Depth: $2662 \mathrm{~m}$

Sediment Thickness: $280 \mathrm{~m}$

Total Penetration: $280 \mathrm{mbsf}$ (stop at first basement recovery)

Seismic Coverage: Line 95-23a, SP 615 (Fig. 9, Appendix 1C)

Objectives: The Lithospheric Heat Flow site extends the hydrothermal transition transect to where the upper crust should be fully sealed by low-permeability sediment. The conductive heat flow through the sediment section should reflect the total for lithosphere of this relatively young age $(\sim 2.5 \mathrm{Ma})$.

\section{Drilling Program: APC/XCB}

Logging and Downhole: Frequent APC and Probe temperature measurements, particularly near basement

Nature of Rock Anticipated: Turbidite sediments, altered basalt 


\title{
SCIENTIFIC PARTICIPANTS
}

Co-Chief Scientist:

Earl Davis

Energy, Mines \& Resources

Pacific Geoscience Centre

9860 West Saanich Rd.

P.O. Box 6000

Sydney, B.C. V8L 4B2

Canada

E-mail: davis@pgc.emr.ca

Work Phone: (604) 363-6453

Fax: (604) 363-6565

Co-Chief Scientist: Andrew Fisher

Earth Sciences Department

University of California, Santa Cruz

Earth Sciences Building

Santa Cruz, CA 95064

U.S.A.

E-mail: afisher@earthsci.ucsc.edu

Work Phone: (408) 459-5598

Fax: (408) 459-3074

Staff Scientist:

John Firth

Ocean Drilling Program

1000 Discovery Drive

Texas A\&M Research Park

College Station, TX 77845-9547

U.S.A.

E-mail: john_firth@odp.tamu.edu

Work Phone: (409) 845-0507

Fax: (409) 845-0876

Petrologist:

\author{
Marc Constantin \\ Marine Geology Research Laboratory \\ Dept. Of Geology \\ University of Toronto \\ 22 Russell St. \\ Toronto, Ontario, M5S 3B1 \\ Canada \\ E-mail: mconstan@quartz.geology.utoronto.ca \\ Work Phone: (416) 978-0833 \\ Fax: (416) 978-3938
}

Petrologist:
Arlëne Hunter
Dept. of Earth Sciences
University of Leeds
Leeds LS2 9JT
United Kingdom
E-mail: arlene@earth.leeds.ac.uk
Work Phone: (44) 1-13-233-5234
Fax: (44) 1-13-233-5259 
Petrologist:

Sedimentologist:

Sedimentologist:

Sedimentologist:

Sedimentologist:
David A. Vanko

Dept. of Geology

Georgia State University

University Plaza

Atlanta, GA 30303-3083

U.S.A.

E-mail: geodav@gsusgil.gsu.edu

Work Phone: (404) 651-2272

Fax: (404) 651-1376

Kimberly A. Brown

Scripps Institution of Oceanography

University of California, San Diego

La Jolla, CA 92093

E-mail: k1brown@ucsd.edu

Work Phone: (619) 534-1826

Fax: (619) 534-0784

Martine D. Buatier

Laboratoire de Sédimentologie et Géodynamique

Université de Lille I

URA 719 UFR des Sciences de la Terre

F-59655 Villeneuve d'Ascq

France

E-mail: martine buatier@univ-lille1.fr

Work Phone: (33) 20-43-43-95

Fax: (33) 20-43-49-10

Atsuyuki Inoue

Dept. of Earth Sciences

Chiba University

Chiba 263

Japan

E-mail: atinoue@earth.s.chiba-u.ac.jp

Work Phone: (81) 43-290-3712

Fax: (81) 43-290-3715

Michael B. Underwood

Department of Geological Sciences

University of Missouri, Columbia

101 Geology Building

Columbia, MO 65211

U.S.A.

E-mail: geoscmbu@ showme.missouri.edu

Work Phone: (314) 882-4685

Fax: (314) 882-5458 
Physical Properties Specialist: Kan Aoike

Ocean Research Institute

University of Tokyo

1-15-1 Minamidai

Nakano-ku

Tokyo 164

Japan

E-mail: bleupond@ ori.u-tokyo.ac.jp

Work Phone: (81) 3-5351-6438

Fax: (81) 3-5351-6438

Physical Properties Specialist: Jeffrey T. Martin

Georgia Institute of Technology

School of Earth \& Atmospheric Science

Atlanta, GA 30331-0340

U.S.A.

E-mail: martinj@namazu.eas.gatech.edu

Work Phone: (404) 894-2862

Fax: (404) 853-0232

Physical Properties Specialist: $\quad$ Danial F.C. Pribnow

Dept. of Geology \& Geophysics

University of Utah

717 Browning Bldg.

Salt Lake City, UT 84112

U.S.A.

E-mail: dpribnow@mines.utah.edu

Work Phone: (801) 581-3588

Fax: (801) 581-7065

Physical Properties Specialist: Joshua S. Stein

Earth Sciences Department

University of California, Santa Cruz

Earth Sciences Building

Santa Cruz, CA 95064

U.S.A.

E-mail: jstein@earthsci.ucsc.edu

Work Phone: (408) 459-2838

Fax: (408) 459-3074

Inorganic Geochemist: Henry Elderfield

Dept. of Earth Sciences

University of Cambridge

Cambridge CB2 3EQ

United Kingdom

E-mail: he101@esc.cam.ac.uk

Work Phone: (44) 1223-333-406

Fax: (44) 1223-333-450

Inorganic Geochemist: Christophe Monnin

Laboratoire de Géochimie

Université Paul Sabatier

38 rue des Trente Six Ponts

31400 Toulouse

France 
E-mail: monnin@lucid.ups-tlse.fr

Work Phone: (33) 61-55-62-41

Fax: (33) 61-52-05-44

Inorganic Geochemist:

Michael J. Mottl

Department of Oceanography/SOEST

University of Hawaii at Manoa

1000 Pope Road

Honolulu, HI 96822

U.S.A.

E-mail: mmottl@soest.hawaii.edu

Work Phone: (808) 956-7006

Fax: (808) 956-9225

Inorganic Geochemist:

Charles G. Wheat

WCNURC

P.O. Box 475

Moss Landing, CA 95039-0475

U.S.A.

E-mail: wheat@mbari.org

Work Phone: (408) 633-7033

Fax: (408) 633-6872

Organic Geochemist:

Eva Margot Andersson

Geologiska Institutionen

Stockholms Universitet

S-106 91 Stockholm

Sweden

E-mail: eva.andersson@geokem.su.se

Work Phone: (46) 816-4738

Fax: (46) 834-5808

Paleontologist (nannos): $\quad$ Xin $\mathrm{Su}$

GEOMAR

Christian-Albrechts-Universität zu Kiel

Wischhofstrasse 1-3

Gebaude 4

D-24148 Kiel

Federal Republic of Germany

E-mail: xsu@geomar.de

Work Phone: (49) 431-720-2172

Fax: (49) 431-725-391

Paleomagnetist:

Roisin M. Lawrence

Department of Geology

Duke University

P.O. Box 90229

Durham, N.C. 27708-0229

U.S.A.

E-mail: lawrence@geo.duke.edu

Work Phone: (919) 681-8165

Fax: (919) 684-5833

JOIDES Logger: Keir Becker

Rosenstiel School of Marine and 


\begin{tabular}{|c|c|}
\hline & $\begin{array}{l}\text { Atmospheric Science } \\
\text { University of Miami } \\
\text { Division of Marine Geology and Geophysics } \\
\text { 4600 Rickenbacker Causeway } \\
\text { Miami, FL 33149-1098 } \\
\text { U.S.A. } \\
\text { E-mail: kbecker@ rsmas.miami.edu } \\
\text { Work Phone: (305) 361-4661 } \\
\text { Fax: (305) 361-2352 }\end{array}$ \\
\hline JOIDES Logger: & $\begin{array}{l}\text { Jens S. Grigel } \\
\text { Universität Bremen } \\
\text { FB 5 } \\
\text { Klagenfurter Straße } \\
\text { D-28359 Bremen } \\
\text { Federal Republic of Germany } \\
\text { E-mail: jgrigel@geophys2.uni-bremen.de } \\
\text { Work Phone: (49) 421-218-7162 } \\
\text { Fax: (49) 421-218-7163 }\end{array}$ \\
\hline LDEO Logger: & $\begin{array}{l}\text { Carlos Goncalves } \\
\text { Dept. Of Geology } \\
\text { University of Leicester } \\
\text { University Road } \\
\text { Leicester LE1 7RH } \\
\text { United Kingdom } \\
\text { E-mail: n/a } \\
\text { Work Phone: n/a } \\
\text { Fax: (44) 116-252-3918 }\end{array}$ \\
\hline LDEO Logger Trainee: & $\begin{array}{l}\text { Yue-feng Sun } \\
\text { Lamont-Doherty Earth Observatory } \\
\text { Columbia University } \\
\text { Borehole Research Group } \\
\text { Palisades, NY } 10964 \\
\text { U.S.A. } \\
\text { E-mail: suny @ ldeo.columbia.edu } \\
\text { Work Phone: (914) 359-2900 } \\
\text { Fax: (914) 365-3182 }\end{array}$ \\
\hline Schlumberger Engineer: & $\begin{array}{l}\text { Steve Kittredge } \\
\text { Schlumberger Offshore Services } \\
\text { 369 Tristar Dr. } \\
\text { Webster, TX } 77598 \\
\text { U.S.A. }\end{array}$ \\
\hline Operations Manager: & $\begin{array}{l}\text { Michael Storms } \\
\text { Ocean Drilling Program } \\
\text { Texas A\&M University Research Park } \\
\text { 1000 Discovery Drive } \\
\text { College Station, Texas 77845-9547 } \\
\text { U.S.A. } \\
\text { E-mail: michael_storms @ odp.tamu.edu } \\
\text { Work Phone: (409) 845-2101 } \\
\text { Fax: (409) 845-2308 }\end{array}$ \\
\hline
\end{tabular}


Development Engineer:

Visiting Engineer:

Laboratory Officer:

Assistant Laboratory Officer/ Marine Laboratory Specialist (X-ray):

Marine Laboratory Specialist/ Yeoperson:

Marine Laboratory Specialist/ Curatorial Representative:
Bill Rhinehart

Ocean Drilling Program

Texas A\&M University Research Park 1000 Discovery Drive

College Station, Texas 77845-9547

U.S.A.

E-mail: bill_rhinehart@odp.tamu.edu

Work Phone: (409) 845-2265

Fax: (409) 845-2308

Robert McDonald

Pacific Geoscience Centre

Geological Survey of Canada

9860 West Saanich Road

P.O. Box 6000

Sidney, British Columbia V8L 4B2

Canada

E-mail: n/a

Work Phone: n/a

Fax: (604) 363-6565

Burney Hamlin Ocean Drilling Program

Texas A\&M University Research Park 1000 Discovery Drive

College Station, Texas 77845-9547

U.S.A.

E-mail: burney_hamlin@odp.tamu.edu Work Phone: (409) 845-5716

Fax: (409) 845-2380

Kuro Kuroki

Ocean Drilling Program

Texas A\&M University Research Park

1000 Discovery Drive

College Station, Texas 77845-9547

U.S.A.

E-mail: kuro_kuroki@odp.tamu.edu

Work Phone: (409) 845-8482

Fax: (409) 845-2380

Jo Ribbens

Ocean Drilling Program

Texas A\&M University Research Park

1000 Discovery Drive

College Station, Texas 77845-9547

U.S.A.

E-mail: jo_ribbens@odp.tamu.edu

Work Phone: (409) 845-8482

Fax: (409) 845-2380

Erinn McCarty

Ocean Drilling Program 
Texas A\&M University Research Park 1000 Discovery Drive

College Station, Texas 77845-9547

U.S.A.

E-mail: erinn_mccarty@odp.tamu.edu

Work Phone: (409) 845-8482

Fax: (409) 845-2380

Marine Computer Specialist/
System Manager:

Marine Computer Specialist/ System Manager:

Marine Laboratory Specialist/ Storekeeper:

Marine Laboratory Specialist/ X-ray:

Marine Laboratory Specialist/ Chemistry:
Matt Mefferd

Ocean Drilling Program

Texas A\&M University Research Park 1000 Discovery Drive

College Station, Texas 77845-9547

U.S.A.

E-mail: matt_mefferd@odp.tamu.edu

Work Phone: (409) 862-4847

Fax: (409) 845-4857

Terry Klepac

Ocean Drilling Program

Texas A\&M University Research Park

1000 Discovery Drive

College Station, Texas 77845-9547

U.S.A.

E-mail: terry_klepac@odp.tamu.edu

Work Phone: (409) 862-4849

Fax: (409) 845-4857

Sandy Dillard

Ocean Drilling Program

Texas A\&M University Research Park 1000 Discovery Drive

College Station, Texas 77845-9547

U.S.A.

E-mail: sandy_dillard@odp.tamu.edu

Work Phone: (409) 845-2480

Fax: (409) 845-2380

Jaque Ledbetter

Ocean Drilling Program

Texas A\&M University Research Park

1000 Discovery Drive

College Station, Texas 77845-9547

U.S.A.

E-mail: jaque_ledbetter@odp.tamu.edu

Work Phone: (409) 845-8482

Fax: (409) 845-2380

Tim Bronk

Ocean Drilling Program

Texas A\&M University Research Park 1000 Discovery Drive

College Station, Texas 77845-9547 U.S.A. 
E-mail: tim_bronk@odp.tamu.edu

Work Phone: (409) 845-2480

Fax: (409) 845-2380

Marine Laboratory Specialist/ Chemistry:

Anne Pimmel

Ocean Drilling Program

Texas A\&M University Research Park

1000 Discovery Drive

College Station, Texas 77845-9547

U.S.A.

E-mail: anne_pimmel@odp.tamu.edu

Work Phone: (409) 845-2485

Fax: (409) 845-2380

Marine Laboratory Specialist/ Magnetics:

Margaret Hastedt

Ocean Drilling Program

Texas A\&M University Research Park

1000 Discovery Drive

College Station, Texas 77845-9547

U.S.A.

E-mail: margaret_hastedt@odp.tamu.edu

Work Phone: (409) 845-2483

Fax: (409) 845-2380

Marine Laboratory Specialist/ Phys. Props.:

Greg Lovelace

Ocean Drilling Program

Texas A\&M University Research Park

1000 Discovery Drive

College Station, Texas 77845-9547

U.S.A.

E-mail: greg_lovelace@odp.tamu.edu

Work Phone: (409) 845-2481

Fax: (409) 845-2380

Marine Laboratory Specialist/ Photo:

Roy Davis

Ocean Drilling Program

Texas A\&M University Research Park

1000 Discovery Drive

College Station, Texas 77845-9547

U.S.A.

E-mail: roy_davis@odp.tamu.edu

Work Phone: (409) 845-8482

Fax: (409) 845-4857

Marine Laboratory Specialist/ DHL/TS/Fantail:

Chris Nugent

Ocean Drilling Program

Texas A\&M University Research Park

1000 Discovery Drive

College Station, Texas 77845-9547

U.S.A.

E-mail: chris_nugent@odp.tamu.edu

Work Phone: (409) 845-2480

Fax: (409) 845-2380 
Marine Laboratory Specialist/ UWG:

Marine Electronics Specialist:
Monty Lawyer

Ocean Drilling Program

Texas A\&M University Research Park

1000 Discovery Drive

College Station, Texas 77845-9547

U.S.A.

E-mail: monty_lawyer@odp.tamu.edu

Work Phone: (409) 845-2480

Fax: (409) 845-2380

Bill Stevens

Ocean Drilling Program

Texas A\&M University Research Park 1000 Discovery Drive

College Station, Texas 77845-9547

U.S.A.

E-mail: bill_stevens@odp.tamu.edu

Work Phone: (409) 845-2454

Fax: (409) 845-2380

Marine Electronics Specialist: Mark Watson

Ocean Drilling Program

Texas A\&M University Research Park

1000 Discovery Drive

College Station, Texas 77845-9547

U.S.A.

E-mail: mark_watson@odp.tamu.edu

Work Phone: (409) 845-2473

Fax: (409) 845-2380

TECH STAFF SUBJECT TO CHANGE. 